\title{
Peatland and wetland ecosystems in Peruvian Amazonia: indigenous classifications and perspectives
}

\author{
$\underline{\text { Christopher Schulz }}^{1}$, Manuel Martín Brañas $^{2}, \underline{\text { Cecilia Núñez Pérez }}^{2}$, Margarita Del Aguila Villacorta $^{2}, \underline{\text { Nina Laurie }}^{3}, \underline{\text { Ian T. Lawson }}^{3}$ \\ and Katherine H. Roucoux ${ }^{3}$
}

\begin{abstract}
Many indigenous people hold detailed ecological knowledge about their environment and have developed complex classifications of ecosystem types in their own languages. These classification systems may be based on characteristics including the availability of key resources, salient plant species, and cultural factors, among others. Indigenous environmental knowledge has been of interest to (ethno-)ecologists, geographers, anthropologists, and other scientists looking to learn from indigenous people, especially in newly emerging research topics. We identified and interpreted an ecosystem classification system of the Urarina, a small indigenous nation based in the Chambira River basin, a peatland-rich area of Peruvian Amazonia. Our findings, based on semistructured interviews, participatory mapping exercises, and site visits, indicate that the Urarina distinguish between ecosystems according to vegetation physiognomy, certain (palm) tree species, hydrology, and soil appearance, and that their use of natural resources varies between different ecosystems. Two Urarina ecosystems, jiiri and alaka, are almost certainly associated with the presence of peat soils and are of special cultural significance. The Urarina ecosystem classification system thus offers insights and inspiration for ecologists studying peatlands and other wetlands in the Peruvian Amazon who, thus far, have mostly focused on floristic and structural analyses only. Not least, our research highlights the importance of the peatlands for local people, beyond their role for the global climate system as a substantial carbon store.
\end{abstract}

Key Words: Amazon; ecosystem classification; indigenous knowledge; Peru; tropical peatlands; Urarina

\section{INTRODUCTION}

Through millennia of experience and interaction with certain environments, many indigenous peoples have developed sophisticated and culturally specific environmental knowledge systems (Berkes et al. 1998, Davidson-Hunt and Berkes 2003, Folke 2004, Sileshi et al. 2009). These knowledge systems express themselves not just in the information that indigenous people hold, for example, about traditional medicinal plants, game species, or climate patterns, but also in their daily practices and in their wider beliefs and worldviews, often termed cosmovision, cosmology, or "kosmos" (Toledo 1992, Toledo and BarreraBassols 2009). One important element of indigenous environmental knowledge systems is the classification of habitats, ecosystems, or landscapes (Berkes et al. 1998, Omotayo and Musa 1999, Shepard et al. 2001, Davidson-Hunt and Berkes 2003, Duvall 2008, Levinson 2008, Johnson and Davidson-Hunt 2011, Molnár 2013, Wartmann and Purves 2018). Such classification systems rely on various indicators to delimit boundaries between spatial units. These may be related to the vegetation, e.g., the presence of certain salient plant species, or abiotic factors such as soil types, hydrology, or topography of an area. Studies of indigenous classification systems have been conducted in many different contexts around the globe, e.g., to identify rain forest habitats with the Matsigenka of the Peruvian Amazon (Shepard et al. 2001), habitat types recognized by traditional herders in the Hungarian Hortobágy salt steppe (Molnár 2013), physical geographic concepts of Maninka farmers in Mali (Duvall 2008), or the landscape and seascape terminology of the inhabitants of Rossel Island, Papua New Guinea (Levinson 2008).
Interest in indigenous knowledge systems remains strong among ethnoecologists, anthropologists, geographers, environmental social scientists, and policy makers (Pascual et al. 2017, Tengö et al. 2017), even if the boundaries between indigenous and nonindigenous knowledge remain the subject of considerable academic debate (Agrawal 1995, 2009, Leach and Fairhead 2002, Ludwig 2016, 2017, Löfmarck and Lidskog 2017). Studies of indigenous knowledge, including ecosystem classification systems, are considered to be important for at least four reasons:

1. Understanding indigenous ecosystem classifications contributes to making sense of the underlying worldviews that shape naming practices in the first place (Hunn 1996, Duvall 2008, Levinson 2008). Associated with this, linguists, ethnogeographers, and others have made attempts to formulate general theories of place-naming practices (e.g., Hunn 1996, Smith and Mark 2003, Levinson 2008).

2. Indigenous knowledge is frequently viewed as the cultural heritage of indigenous nations that may potentially be lost through processes of cultural assimilation into dominant mainstream societies (Shepard et al. 2001, Hance 2015, Ens et al. 2016). Its documentation through academic research may safeguard this cultural heritage for its intrinsic value, as well as for potential use in education and cultural engagement activities.

3. Indigenous knowledge may be a potential "shortcut" for the development of conventional science, e.g., where local people may have more detailed knowledge of local ecosystems and species than foreign ecologists or a better

\footnotetext{
${ }^{1}$ Department of Geography, University of Cambridge, United Kingdom, ${ }^{2}$ Amazonian Cultural Diversity and Economy Research Programme, Peruvian Amazon Research Institute (IIAP), Iquitos, Peru, ${ }^{3}$ School of Geography and Sustainable Development, University of St Andrews, United Kingdom
} 
understanding of habitats at a local scale (Fleck and Harder 2000, Shepard et al. 2001, Sheil and Lawrence 2004). It may also function as a reference for comparison, dialogue, and a benchmark for the quality of scientific knowledge via ground truthing and cross validation (Robbins 2003, Fernández-Llamazares et al. 2017, ReyesGarcía et al. 2018), e.g., where local forest types defined by indigenous people are compared with habitat types identified through remote sensing and statistical ecological analysis (Abraão et al. 2008).

4. Awareness of indigenous knowledge is often considered useful for improving environmental management (Stevenson 1996, Berkes et al. 2000, Puri 2007, Sileshi et al. 2009, Steele and Shackleton 2010, Armatas et al. 2016). Sometimes this may be because of its capacity to increase exploitation and production of natural resources, e.g., by increasing agricultural yields via an improved understanding of soil diversity (Rainey 2005, Pereira et al. 2017). It may also inform and strengthen environmental conservation partnerships with indigenous people by adapting conservation measures to local knowledge systems and thereby increasing their acceptance by indigenous partners (Chapin 2004, Sheil and Lawrence 2004, Ens et al. 2016).

Although some authors have stressed a need for describing indigenous knowledge purely on its own terms (e.g., Duvall 2008), most studies in the field still aim to achieve varying levels of dialogue, comparison, or complementarity between indigenous and "scientific" knowledge, not least because boundaries between the two types of knowledge are inevitably arbitrary (Robbins 2003). Evidence of the arbitrary distinction between knowledges is that indigenous knowledge is considered useful for scientific knowledge in the first place, although Ludwig (2017) cautions that there is a risk of crowding out those aspects of indigenous and local knowledge that are deemed "not useful" by Western scientists. Some authors may also prefer the term "science-based knowledge" instead of "scientific knowledge" (e.g., O'Flaherty et al. 2008), possibly to highlight that the boundary between the different knowledge systems is primarily defined by the application of scientific methods. In line with Raymond et al. (2010), we define "indigenous knowledge" as knowledge held by a certain indigenous nation, and, following Andolina et al. (2009:178), we understand it "in sociocultural, relational terms instead of space-bound understandings that fix knowledge to particular local areas." In this way, we place an emphasis on diverse ways of knowing and processes of learning, where dialogue can be generated between different knowledge communities, across the diversity among indigenous communities, as well as conventional (Western) science.

We contribute to the literature on indigenous ecosystem classification systems with a study of Urarina classifications of their environment in the Loreto Region of Peruvian Amazonia. The Urarina are an indigenous nation of about 3000 members who live in small communities in the Chambira River basin of the Peruvian Amazon, in the challenging environment of nutrient-poor blackwater river systems and associated wetlands, swamps, and seasonally flooded forests, with little perennially dry land (Kramer 1979, Witzig and Ascencios 1999, Olawsky 2006, Roucoux et al. 2017). Urarina ways of classifying their environment might be of global relevance, given that they live in the midst of what appears to be the largest peatland complex in Amazonia, only recently recognized as such by physical geographers and ecologists. Other tropical peatlands of global relevance are located in the Congo Basin (Dargie et al. 2017) and in Southeast Asia (Couwenberg et al. 2010), and the latter are under threat from fires (Turetsky et al. 2015) and conversion to agriculture, such as oil palm plantations (Koh et al. 2009). The large quantity of carbon processed and stored by these peatforming wetlands means that they are a significant component of the global climate system (Freitas Alvarado et al. 2006, Lähteenoja et al. 2012, Draper et al. 2014, Roucoux et al. 2017). Thus, we placed special emphasis on identifying whether the boundary between peatland and nonpeatland ecosystems was meaningful to the Urarina.

It has sometimes been suggested that the difficult environment of peatlands has acted as a natural barrier or "shelter" that has helped to maintain the cultural integrity of the Urarina since colonial times (Witzig and Ascencios 1999), even if there are marked differences between different settlement areas, depending on their accessibility (Kramer 1979). Peatlands around the globe play an important part in the cultural imaginary of people who live close to them, because of their distinct physical and ecological features (Lehtinen 2000, Byg et al. 2017), although this aspect tends to be underexplored for tropical peatlands so far. Research on local ecosystem classifications has not yet systematically explored whether terminology for peatland ecosystems exists in indigenous languages, one of the research gaps that we are trying to address. In the Peruvian Amazon, for example, some sociocultural assessments focus on certain locally known ecosystem types such as aguajales, i.e., palm swamps dominated by the palm species Mauritia flexuosa, locally known as aguaje, which may or may not coincide with the presence of peat in the ground (Gilmore et al. 2013), but there is likely to be some overlap between aguajales and peatland ecosystems (Freitas Alvarado et al. 2006).

Previous research in Urarina communities has been conducted by linguists (e.g., Cajas Rojas et al. 1987, Manus 1992, Olawsky 2002, 2006) and by ethnographers and anthropologists (e.g., Tessmann 1930, Kramer 1977, 1979, Díaz Barba 1987, Dean 1994, 1999, 2009, Walker 2013a, b, Fabiano 2015). There are about 2000 speakers of Urarina, an isolated language with unique linguistic features (Olawsky 2006). The Urarina have a long history of oppression and exploitation by their neighbors, which precedes colonization of the area by the Spanish from the 17 th century onward (Dean 2009, Walker 2013b). Although they had extended contact with Jesuit missionaries in the 17th and 18th centuries and continue to be visited by North American and Argentinean evangelical missionaries today, they conserve a strong separate cultural identity and are officially recognized as an indigenous nation by the Peruvian state. Previous ethnographic research has considered Urarina agricultural techniques (Kramer 1977, Díaz Barba 1987); socioeconomic interactions with patrones, i.e., nonindigenous resource extractors hiring indigenous workers within an asymmetric power relationship (Kramer 1979, Dean 1999); the role of shamans and consumption of hallucinogenic ayahuasca (Fabiano 2015); and marriage 
patterns, childhood, and adolescence, as well as gender relations (Dean 2009, Walker 2013b). Gender differences are extremely marked (Walker 2013b). For example, only men interact with outsiders, speak (limited) Spanish, wear nontraditional clothes, and have adopted "foreign" pastimes such as playing football. In contrast, most Urarina women do not typically talk to outsiders, do not speak Spanish, do wear traditional clothes, and are, in this way, stewards of the cultural heritage of this indigenous nation (Walker 2013a,b), like women in many other indigenous settings in the wider Amazonian-Andean region (Andolina et al. 2009).

Overall, our aim is to identify and interpret Urarina ecosystem classifications for the first time to help establish the importance of indigenous understandings of peatland and wetland ecosystems to academic debate. This serves several purposes: first, it may help conventional scientists to advance their thinking regarding the classification of ecosystems in the peatland-rich environments where the Urarina traditionally live, the detailed floristic description of which has only recently begun (Lähteenoja et al. 2012, Draper et al. 2018). Second, it gives the first insights into the role and naming of peatlands among local people in the Peruvian Amazon, a research question that has so far not been investigated (Roucoux et al. 2017). Third, it contributes to documenting an aspect of Urarina culture that has so far not been systematically studied, at a time when their cultural heritage is at risk of being lost through weakened interest among younger generations (Olawsky 2006).

\section{MATERIALS AND METHODS}

Fieldwork took place in March/April 2018 in the Urarina community of Nueva Unión, located on the Espejo River, one of the tributaries of the Chambira River, which is part of the wider Pastaza-Marañón Basin in the Loreto Region of Peruvian Amazonia (Fig. 1). It consisted of semistructured interviews with community members, participatory mapping exercises, and site visits, which are established methods for the study of indigenous ecosystem classification systems (Johnson and Davidson-Hunt 2011).

In total, 20 semistructured interviews were carried out collaboratively by the first 4 authors of this article with 27 community members overall, representing roughly a third of the overall adult population of the community. Interviewees ranged in age from 18 to 72 years old and included 20 men who were interviewed in Spanish and 7 women who were interviewed in Urarina with the help of a local translator. All male interviewees engaged in hunting, fishing, and small-scale subsistence farming of manioc, plantain, corn, sweet potato, and other crops (see Table 1 for full species names) or had at least some experience with these activities. The majority were also active in the seasonal trade of palm hearts, locally known as chonta, harvested from the wild palm tree species Euterpe precatoria, and aguaje fruit, from the wild palm Mauritia flexuosa (Delgado et al. 2007, Balslev et al. 2008, Smith 2015, Virapongse et al. 2017), and some had been working on the maintenance of an oil pipeline that crosses the community's territory. Further professions represented were two primary school teachers, who earned a salary from the Peruvian state, and a pastor. Female interviewees were in charge of child care, cooking, collection of firewood, fishing, washing clothes, and production of traditional textiles, among other activities.

Fig. 1. (a) Location of the Pastaza-Marañón Basin in western Amazonia (dashed box); (b) inset showing the Pastaza-

Marañón Basin, with the modeled distribution of peatlands following Draper et al. (2014) in gray. The study area, around the Chambira River basin, is indicated.

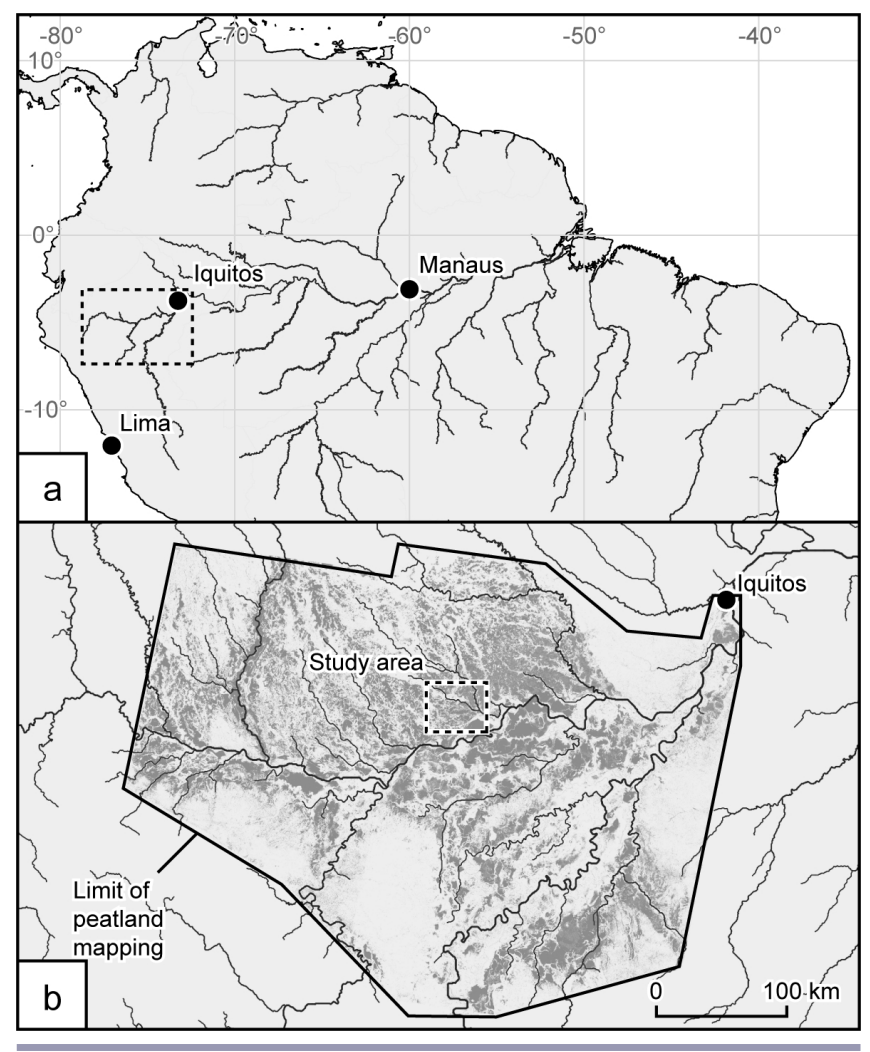

The main topics covered in interviews, relevant to us, were (1) natural resource use, especially hunting, fishing, and timber and nontimber (forest) product harvesting; (2) classification of the surrounding environment into various ecosystem categories in the Urarina language and their indicators (see Urarina ecosystem classification for further details); and (3) cultural and mythological importance of certain ecosystem types and associated traditional beliefs and stories. All interviews were recorded and transcribed in Spanish; analytical categories within the interview transcripts were coded with NVivo 11 to facilitate the qualitative analysis.

These semistructured interviews were complemented with participatory mapping exercises, which were employed as a visual tool to facilitate discussions on the classification of the various areas surrounding the community. One full-day community mapping workshop was held at the beginning of fieldwork, in which 5 groups of 8 to 12 people, separated by gender, worked on 1 large map each to identify a tentative list of Urarina ecosystems that could then be discussed in subsequent interviews. During this workshop, community members described their use of natural resources, as well as the terrain surrounding their community. 
Table 1. List of species.

\begin{tabular}{|c|c|c|}
\hline$\underline{\text { Scientific Name }}$ & Local Spanish Name & English Name or Approximation \\
\hline Alouatta seniculus & Coto & Venezuelan red howler \\
\hline Attalea butyracea & Shebón & A palm tree \\
\hline Biotodoma sp. & Bujurqui & Cichlid fishes \\
\hline Bradypus variegatus & Oso perezoso & Brown-throated sloth \\
\hline Brycon sp. & Sábalo & Brycon (a fish) \\
\hline Caiman crocodilus & Lagarto blanco & Spectacled caiman \\
\hline Calophyllum brasiliense & Lagarto caspi & A tall hardwood tree \\
\hline Calycophyllum spruceanum & Capirona & A hardwood tree \\
\hline Cedrela odorata & Cedro & A tall timber tree \\
\hline Chelonoidis denticulata & Motelo & Yellow-footed tortoise \\
\hline Choloepus hoffmanni & Oso perezoso & Hoffmann's two-toed sloth \\
\hline Copaifera officinalis & Copaiba & Hardwood trees \\
\hline Coussapoa sp. & Renaco & Hardwood trees \\
\hline Cuniculus paca & Majás & Lowland paca \\
\hline Dasyprocta fuliginosa & Añuje & Black agouti \\
\hline Dasypus sp. & Carachupa & Armadillo \\
\hline Dracaena guianensis & Camaleón & Northern caiman lizard \\
\hline Eunectes murinus & Boa & Boa/anaconda \\
\hline Euterpe precatoria & Huasaí, chonta & A tall palm tree \\
\hline Ficus sp. & Renaco & Hardwood trees \\
\hline Hoplerythrinus unitaeniatus & Shuyo & Aimara (a fish) \\
\hline Ipomoea batatas & Camote & Sweet potato \\
\hline Iryanthera sp. & Cumala & Tall timber trees \\
\hline Manihot esculenta & Yuca & Manioc \\
\hline Mauritia flexuosa & Aguaje & An abundant, tall palm tree \\
\hline Mazama sp. & Venado & Deer \\
\hline Melanosuchus niger & Lagarto negro & Black caiman \\
\hline Musa sp. & Plátano & Plantain \\
\hline Mylossoma duriventre & Palometa & Silver mylossoma (a fish) \\
\hline Nasua nasua & Achuni & Ring-tailed coati \\
\hline Pachira brevipes & $\begin{array}{l}\text { Jiri benüna (in Urarina, i.e., "wood of the } \\
\text { jiiri") }\end{array}$ & A hardwood tree \\
\hline Pecari tajacu & Sajino & Collared peccary \\
\hline Penelope jacquacu & Pucacunga & Spix’s Guan (a bird) \\
\hline Pithecia monachus & Huapo negro & Monk saki (a monkey) \\
\hline Prochilodus nigricans & Boquichico & Black prochilodus (a fish) \\
\hline Psittaciformes & Loro & Parrot \\
\hline Psophia crepitans/leucoptera & Trompetero & $\begin{array}{l}\text { Grey-winged or Pale-winged Trumpeter (a } \\
\text { bird) }\end{array}$ \\
\hline Saimiri boliviensis & Fraile & Black-capped squirrel monkey \\
\hline Simarouba amara & Marupá & A tall timber tree \\
\hline Swietenia macrophylla & Caoba & Mahogany \\
\hline Tapirus terrestris & Sachavaca & Tapir \\
\hline Tayassu pecari & Huangana & White-lipped peccary \\
\hline Tinamus major & Perdiz & Great Tinamou (a bird) \\
\hline Virola sp. & Cumala & Tall timber trees \\
\hline Zea mays & Maíz & Corn \\
\hline
\end{tabular}

Additionally, each interview included an individual mapmaking element, in which interviewees described the areas they had visited, again in view of identifying a local classification system, and the socio-cultural importance of each ecosystem type.

Finally, we also conducted 3 site visits to the various ecosystem types that we identified (see Urarina ecosystem classification) with the guidance of 5 different community members. During these site visits, we had the opportunity to clarify certain characteristics of each ecosystem type in practice and what distinguished ecosystems from each other, especially during the act of crossing from one ecosystem into another. We were also able to collect photographic evidence of the variations in the surrounding environment (see sample photographs in Figs. 2-5). Not least, we were also able to verify with reasonable certainty which ecosystems could be described as peatlands, typically defined as waterlogged areas with at least $30 \mathrm{~cm}$ of organic-rich ( $>65 \mathrm{wt} \%$ organic matter) soil (Lawson et al. 2015, Dargie et al. 2017), and which ecosystems were not, by probing the ground with poles; these can be pushed easily into waterlogged peat, which has a low dry bulk density, typically below $0.15 \mathrm{~g} / \mathrm{cm}^{3}$ (Lawson et al. 2015), but not into soils containing a higher percentage of mineral matter such as silt and clay. 
Fig. 2. A jiiri; this ecosystem consists of "open space" with short vegetation and very soft, waterlogged ground, but note that the jiiri ecosystem may have very diverse appearances.

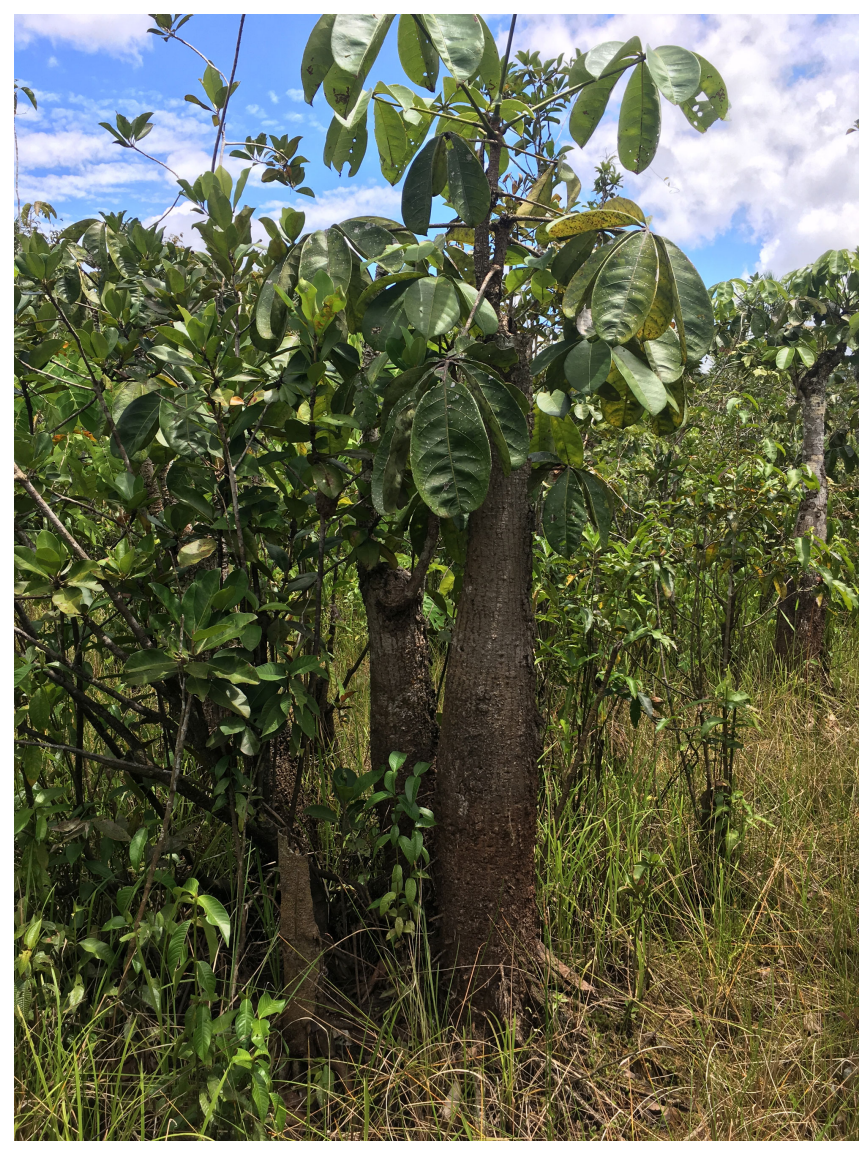

\section{URARINA ECOSYSTEM CLASSIFICATION}

Our investigation of Urarina ecosystems yielded a list of 8 main ecosystem types that are recognized by most community members (see Table 2), of which 2 at least sometimes contain peats up to $1.5 \mathrm{~m}$ in thickness and which may be consistently peat forming. We briefly describe each ecosystem type; Urarina spellings were confirmed with a local school teacher who had been involved in developing the officially recognized Urarina orthography. A preliminary list of ecosystem types was developed following the participatory mapping workshop with the entire community at the beginning of our fieldwork, with some ecosystems being added during individual interviews with community members. To identify each ecosystem's unique features and characteristics, we covered a number of potential indicators during interviews, such as vegetation, i.e., physiognomy and species composition; water regime, i.e., seasonal flooding patterns; soils, i.e., color, muddiness, and "sinkiness"; topography; and human uses, i.e., hunting, fishing, and small-scale farming. Because of our special focus on peatlands, we also included questions on walking experiences, i.e., whether it was easy or difficult to walk in each respective ecosystem, and whether there were problems because of sinking in or having one's boots "sucked" in (in local Spanish:
Fig. 3. An alaka; this ecosystem is defined by the mix of large trees and palm trees, as well as the permanently waterlogged peat soil.

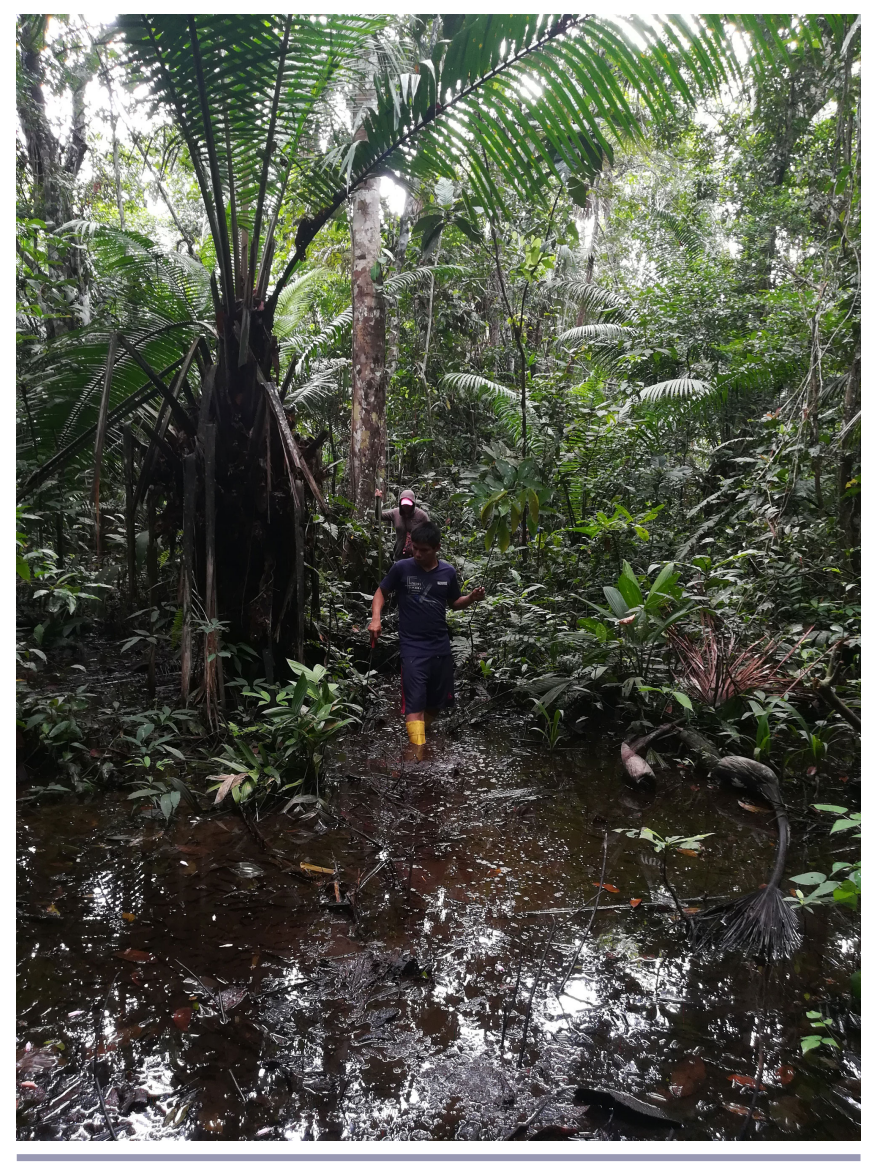

chupadera). Note that for animal and plant species, English names are used where available, and local Spanish names where not. On first appearance, these are complemented with the scientific name (see also Table 1).

\section{Jiiri}

The jiiri ecosystem is highly variable in its appearance (see Fig. 2 for an example). It may include small lakes and ponds, areas of grasses and sedges, a mix of aguaje palm trees with areas of pole forest, i.e., closely spaced, low stature, thin-stemmed trees, known to ecologists in Spanish as varillal (Draper al. 2014, 2018), or pole forest without aguaje. This variability may be explained by the fact that the term jiiri represents a rather abstract concept; several interviewees indicated that its meaning is roughly equivalent to "open space." Consequently, no single translation into local Spanish was given either; the terms aguajal (palm swamp), varillal (pole forest), and pantano (open wetland) were all mentioned in interviews, but there was no clear consensus about the most appropriate translation for jiiri. Aguajal was the most commonly favored Spanish equivalent, but it was also used for the alaka ecosystem (see Urarina ecosystem classification: alaka).

Despite covering different vegetation patterns, compositions, and structures, all jiiris are similar in that their soil shows the 
Fig. 4. The ground in an elelia. This ecosystem consists of mostly dryland forest dominated by the Attalea butyracea palm species; standing water does exist but is much rarer than in the alaka ecosystem.

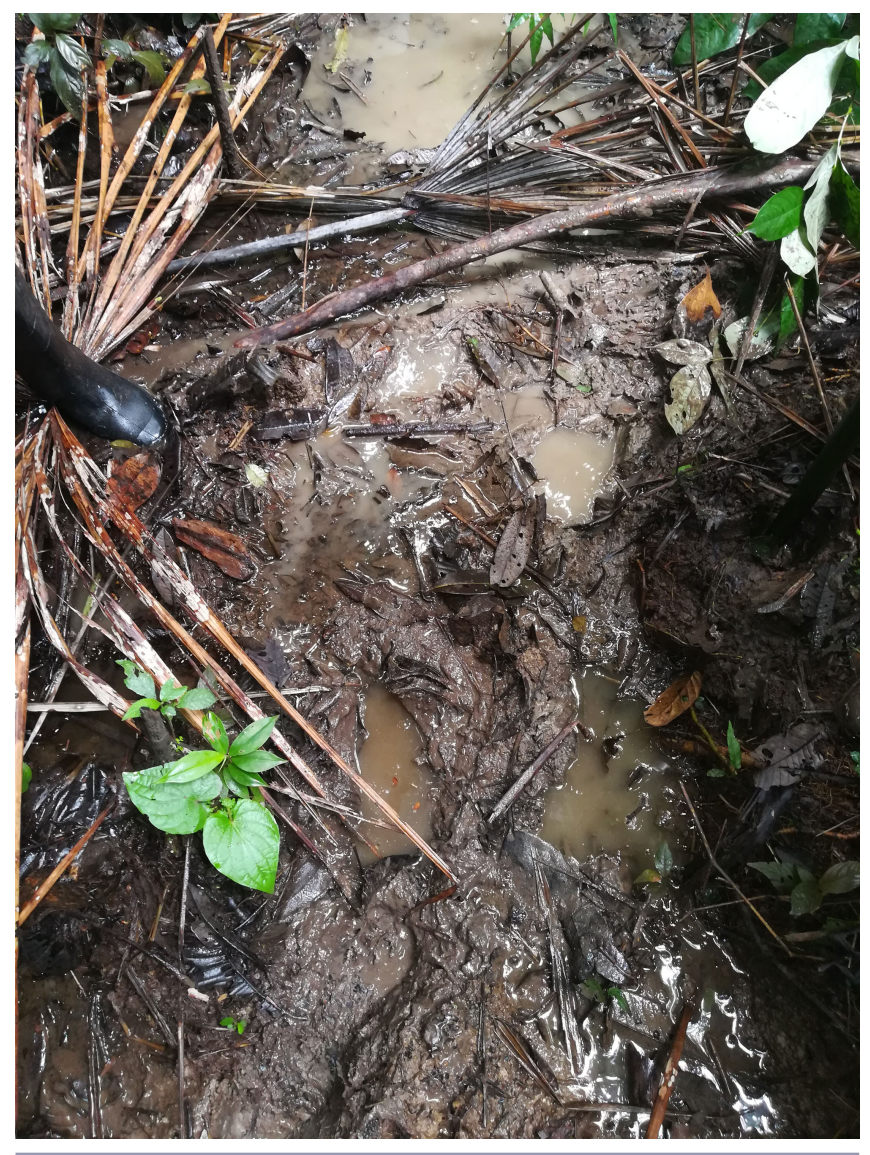

characteristics typical of local peatlands: (1) One can sink in easily; probing during one site visit indicated the presence of at least $1.5 \mathrm{~m}$ of peat, although our guide indicated that the peat thickness may vary between jiiris. (2) They are permanently waterlogged, though only occasionally flooded by river water. (3) Their pore water is dark and transparent, indicating high concentrations of dissolved organic matter. Colors given for the soil ranged from "reddish," which is typical of unhumified peats, to black, which is typical of more decomposed peats. To avoid sinking in, one needs to step on roots of trees wherever possible or cut branches or small trees to walk on where available.

Short trees from jiiri forest can be used for construction, mainly as roof pillars. Some respondents suggested monkeys could be hunted in jiiris, whereas others said this was not possible because of the absence of trees, this disagreement likely being the result of the variability of jiiri appearances. However, there was a consensus that the jiiri is a good hunting ground for tapirs (Tapirus terrestris) and caimans (Caiman crocodilus and Melanosuchus niger); tapirs may sleep and rest in jiiris, whereas caimans usually stay in the little ponds that make up part of a jiiri. Lizards (Dracaena guianensis) and parrots (Psittaciformes), which in the past were occasionally sold alive to wildlife traders from Iquitos,
Fig. 5. A leuuaku; this ecosystem consists of seasonally flooded forest.

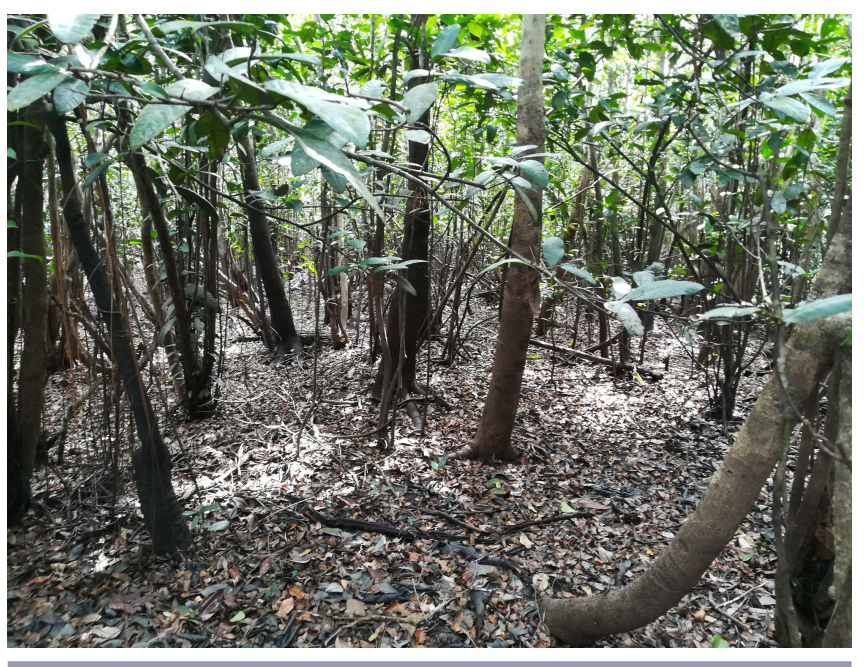

were further mentioned as animals from the jiiri ecosystem. It is also an area where anacondas (Eunectes murinus) can be found, which may only be killed in extremely rare instances of selfdefense.

Respondents differed markedly in their assessment of the importance of jiiris for local people. Some highly valued them as a hunting ground and source of aguaje fruit and stressed their cultural importance (see Interpreting indigenous perspectives on ecosystem classification and peatlands: cultural significance of tropical peatlands); others highlighted the difficulties of the terrain and comparatively lower resource availability and expressed a clear preference for alaka and atane ecosystems, among others.

\section{Alaka}

The alaka ecosystem is characterized by the dominance of aguaje palm trees, which are interspersed with other large timber trees, such as cumala (Virola sp. or Iryanthera sp., known as kaiajuri in Urarina), and further palm tree species such as shebón (Attalea butyracea) or ungurahui (Oenocarpus bataua). Alaka is thus notably darker than jiiri, as less light passes through the canopy (see Fig. 3). It is possible that the name alaka derives from the Urarina word for aguaje, which is alaa (see also Balslev et al. 2008), but some interviewees explicitly disputed this. Because of the dominance of aguaje palm trees, some respondents used the terms alaka and aguajal, i.e., Mauritia flexuosa palm swamp (see Gilmore et al. 2013), interchangeably. Nevertheless, others suggested that jiiris are aguajales, too, so alaka should not be seen as an exact translation of aguajal.

The ground in alakas is again characteristic of a peatland; one can easily sink in, although not necessarily as much as in jiiris; probing during guided site visits showed the presence of $>1.5 \mathrm{~m}$ of peat, and it was often necessary to step on roots or felled small trees to avoid sinking in. Alakas are permanently wet, with less standing water than in jiiris, but are only rarely flooded by river water and must therefore be fed by rainfall and/or groundwater. The soil pore water is transparent but very dark in color, and the 
Table 2. Summary of the characteristics of ecosystem types identified by Urarina interviewees. Where flooding is indicated, this was described as flooding by rivers. "Mud," fango or barro in local Spanish and itanicha in Urarina, is taken to indicate soft substrates that may include peats and wet clayey and silty soils. Possible equivalent terms from the scientific literature on Peruvian wetland vegetation are tentatively indicated, as are the probable equivalent land-cover classes from Draper et al. (2014), although no formal attempt was made in the field to test their strict equivalence.

\begin{tabular}{|c|c|c|c|c|c|c|c|}
\hline Jiiri & Alaka & Atane & Elelia & Leuuaku & Jierune & Kaiajurineeujua & Ujuатіпееијиа \\
\hline \multicolumn{8}{|c|}{ Approximate English equivalent } \\
\hline "Open space" & Palm swamp forest & Dryland forest & $\begin{array}{l}\text { Mostly dryland } \\
\text { forest dominated } \\
\text { by Attalea } \\
\text { butyracea (shebón, } \\
\text { a palm species) }\end{array}$ & $\begin{array}{l}\text { Seasonally flooded } \\
\text { forest }\end{array}$ & $\begin{array}{l}\text { Riparian } \\
\text { seasonally flooded } \\
\text { low-growth forest }\end{array}$ & $\begin{array}{l}\text { Palm swamp forest } \\
\text { dominated by } \\
\text { Virola } \text { sp. or } \\
\text { Iryanthera } \text { sp. } \\
\text { (cumala, a timber } \\
\text { tree) }\end{array}$ & $\begin{array}{l}\text { Palm swamp forest } \\
\text { dominated by } \\
\text { Euterpe precatoria } \\
\text { (huasai or chonta, a } \\
\text { palm species) }\end{array}$ \\
\hline \multicolumn{8}{|c|}{ Vegetation physiognomy } \\
\hline $\begin{array}{l}\text { Highly variable, } \\
\text { ranging from } \\
\text { grassland to short, } \\
\text { thin trees and } \\
\text { palm trees }\end{array}$ & $\begin{array}{l}\text { Mix of large } \\
\text { timber trees and } \\
\text { palm trees }\end{array}$ & $\begin{array}{l}\text { Mix of large } \\
\text { timber trees and } \\
\text { palm trees }\end{array}$ & $\begin{array}{l}\text { Mix of large } \\
\text { timber trees and } \\
\text { palm trees }\end{array}$ & $\begin{array}{l}\text { Mix of large } \\
\text { timber trees and } \\
\text { some palm trees }\end{array}$ & $\begin{array}{l}\text { Short trees and } \\
\text { bushes, lianas, very } \\
\text { dense vegetation }\end{array}$ & $\begin{array}{l}\text { Mix of large } \\
\text { timber trees and } \\
\text { palm trees }\end{array}$ & $\begin{array}{l}\text { Mix of large timber } \\
\text { trees and palm trees }\end{array}$ \\
\hline \multicolumn{8}{|c|}{ Important (palm) tree species with local Spanish name } \\
\hline $\begin{array}{l}\text { Mauritia flexuosa } \\
\text { (aguaje) }\end{array}$ & $\begin{array}{l}\text { Mauritia flexuosa } \\
\text { (aguaje) }\end{array}$ & $\begin{array}{l}\text { No single } \\
\text { dominant species, } \\
\text { but many timber } \\
\text { species }\end{array}$ & $\begin{array}{l}\text { Attalea butyracea } \\
\text { (shebón) }\end{array}$ & $\begin{array}{l}\text { Ficus sp., } \\
\text { Coussapoa sp. } \\
(\text { renaco) }\end{array}$ & $\begin{array}{l}\text { No single } \\
\text { dominant species }\end{array}$ & $\begin{array}{l}\text { Virola } \mathrm{sp} . \text { or } \\
\text { Iryanthera sp. } \\
\text { (cumala) }\end{array}$ & $\begin{array}{l}\text { Euterpe precatoria } \\
\text { (huasail chonta) }\end{array}$ \\
\hline & $\begin{array}{l}\text { Virola } \text { sp. or } \\
\text { Iryanthera } \text { sp. } \\
\text { (cumala) } \\
\text { Attalea butyracea } \\
\text { (shebón) }\end{array}$ & & & & & & \\
\hline \multicolumn{8}{|l|}{ Hydrology } \\
\hline $\begin{array}{l}\text { Permanently wet } \\
\text { soils because of } \\
\text { groundwater, } \\
\text { occasional } \\
\text { flooding from river } \\
\text { water }\end{array}$ & $\begin{array}{l}\text { Permanently to } \\
\text { seasonally wet } \\
\text { soils (but less wet } \\
\text { than jiiri) because } \\
\text { of groundwater } \\
\text { and rainfall, rarely } \\
\text { flooded from river } \\
\text { water }\end{array}$ & Rarely flooded & Rarely flooded & $\begin{array}{l}\text { Flooded for } \\
\text { several months } \\
\text { each year by river } \\
\text { water }\end{array}$ & $\begin{array}{l}\text { Flooded for } \\
\text { several months } \\
\text { each year by river } \\
\text { water }\end{array}$ & $\begin{array}{l}\text { Uncertain, but } \\
\text { likely similar to } \\
\text { alaka }\end{array}$ & $\begin{array}{l}\text { Uncertain, but } \\
\text { likely similar to } \\
\text { alaka }\end{array}$ \\
\hline \multicolumn{8}{|l|}{ Soil and water color } \\
\hline $\begin{array}{l}\text { Red to black soil, } \\
\text { deep mud, water } \\
\text { layer sometimes } \\
\text { present beneath } \\
\text { root mat }\end{array}$ & $\begin{array}{l}\text { Black to brown } \\
\text { soil, deep mud }\end{array}$ & $\begin{array}{l}\text { Brown sandy soil, } \\
\text { little mud except } \\
\text { after heavy rain }\end{array}$ & $\begin{array}{l}\text { Brown to black } \\
\text { soil, shallow muds } \\
\text { at most }\end{array}$ & $\begin{array}{l}\text { Brown to black } \\
\text { soil, muddy only } \\
\text { when flooded }\end{array}$ & $\begin{array}{l}\text { Uncertain, but } \\
\text { likely similar to } \\
\text { leunaku }\end{array}$ & Black soil & $\begin{array}{l}\text { Uncertain, but } \\
\text { likely similar to } \\
\text { alaka }\end{array}$ \\
\hline \multicolumn{8}{|c|}{ Maximum "sinking in" level } \\
\hline Up to chest & Up to waist & None & Feet & Feet & None & Up to knees & Above ankles \\
\hline \multicolumn{8}{|l|}{ Main human uses } \\
\hline $\begin{array}{l}\text { Mauritia flexuosa } \\
\text { (aguaje): fruit, } \\
\text { fiber for textiles }\end{array}$ & $\begin{array}{l}\text { Mauritia flexuosa } \\
\text { (aguaje): fruit, } \\
\text { fiber for textiles }\end{array}$ & & $\begin{array}{l}\text { Attalea butyracea } \\
\text { (shebón): leaves for } \\
\text { roofing }\end{array}$ & & & & $\begin{array}{l}\text { Euterpe precatoria } \\
\text { (huasail chonta): } \\
\text { palm hearts }\end{array}$ \\
\hline $\begin{array}{l}\text { Poles for } \\
\text { construction/ roof } \\
\text { structures, e.g., } \\
\text { Pachira brevipes }\end{array}$ & $\begin{array}{l}\text { Timber for } \\
\text { construction } \\
\text { (floors, walls), e.g., } \\
\text { Virola } \text { sp. or } \\
\text { Iryanthera } \text { sp. }\end{array}$ & $\begin{array}{l}\text { Timber for } \\
\text { construction and } \\
\text { trade, e.g., } \\
\text { Swietenia } \\
\text { macrophylla } \\
\text { (mahogany), } \\
\text { Cedrela odorata } \\
\text { (cedro), } \\
\text { Calycophyllum } \\
\text { spruceanum } \\
\text { (capirona) }\end{array}$ & & $\begin{array}{l}\text { Various timber } \\
\text { tree species, e.g., } \\
\text { Calophyllum } \\
\text { brasiliense (lagarto } \\
\text { caspi); firewood }\end{array}$ & $\begin{array}{l}\text { Poles for } \\
\text { construction/ roof } \\
\text { structures }\end{array}$ & $\begin{array}{l}\text { Virola } \text { sp. or } \\
\text { Iryanthera } \text { sp. for } \\
\text { construction }\end{array}$ & \\
\hline
\end{tabular}




\begin{tabular}{|c|c|c|c|c|c|c|c|}
\hline \multirow[t]{2}{*}{$\begin{array}{l}\text { Hunting for } \\
\text { Tapirus terrestris } \\
\text { (tapir), Caiman } \\
\text { crocodilus, } \\
\text { Melanosuchus } \\
\text { niger (spectacled } \\
\text { and black caiman) }\end{array}$} & $\begin{array}{l}\text { Hunting for } \\
\text { terrestrial } \\
\text { mammals, e.g., } \\
\text { Tapirus terrestris } \\
\text { (tapir), Pecari } \\
\text { tajacu (collared } \\
\text { peccary), Tayassu } \\
\text { pecari (white- } \\
\text { lipped peccary); } \\
\text { monkeys, e.g., } \\
\text { Saimiri boliviensis } \\
\text { (squirrel monkey), } \\
\text { Alouatta seniculus } \\
\text { (red howler); } \\
\text { and birds, e.g., } \\
\text { Penelope jacquacu } \\
\text { (Spix's Guan) }\end{array}$ & $\begin{array}{l}\text { Hunting for } \\
\text { terrestrial } \\
\text { mammals, e.g., } \\
\text { Mazama sp. (deer), } \\
\text { Cuniculus paca } \\
\text { (lowland paca), } \\
\text { Dasyprocta } \\
\text { fuliginosa (black } \\
\text { agouti), Dasypus } \\
\text { novemcinctus/ } \\
\text { kappleri } \\
\text { (armadillo); } \\
\text { Chelonoidis } \\
\text { denticulata } \\
\text { (yellow-footed } \\
\text { tortoise), } \\
\text { monkeys, and } \\
\text { birds, e.g., } \\
\text { Psophia crepitans/ } \\
\text { leucoptera (Grey- } \\
\text { winged or Pale- } \\
\text { winged } \\
\text { Trumpeter), } \\
\text { Tinamus major } \\
\text { (Great Tinamou) }\end{array}$ & $\begin{array}{l}\text { Hunting for the } \\
\text { same animals as in } \\
\text { atane }\end{array}$ & $\begin{array}{l}\text { Fishing with traps, } \\
\text { for example: } \\
\text { Hoplerythrinus } \\
\text { unitaeniatus } \\
\text { (shuyo), Brycon sp. } \\
\text { (sábalo), } \\
\text { Prochilodus } \\
\text { nigricans } \\
\text { (boquichico), } \\
\text { Biotodoma sp. } \\
\text { (bujurqui), } \\
\text { Mylossoma } \\
\text { duriventre } \\
\text { (palometa) }\end{array}$ & \multirow[t]{2}{*}{ Fishing with traps } & & \\
\hline & Seeds for necklaces & & \multicolumn{2}{|l|}{ Seeds for necklaces } & & & \\
\hline \multicolumn{8}{|c|}{ Alternative names in Peruvian Amazonian Spanish (not necessarily strictly equivalent) } \\
\hline $\begin{array}{l}\text { Varillal, aguajal, } \\
\text { pantano }\end{array}$ & Aguajal, shebonal & Restinga, yarinal & Shebonal & $\begin{array}{l}\text { Bajial, tahuampa, } \\
\text { renacal }\end{array}$ & $\begin{array}{l}\text { Bajial, tahuampa, } \\
\text { sogal }\end{array}$ & Cumalar & Chontal \\
\hline \multicolumn{8}{|c|}{ Scientific literature equivalent(s) } \\
\hline $\begin{array}{l}\text { "Open peatland," } \\
\text { "open savanna" } \\
\text { (Lähteenoja et al. } \\
\text { 2009), pole forest/ } \\
\text { varillal } \\
\text { hidromórfico } \\
\text { (Draper et al. } \\
\text { 2014, 2018) }\end{array}$ & $\begin{array}{l}\text { Palm swamp, } \\
\text { aguajal } \\
\text { (Encarnación } \\
\text { 1985, Junk and } \\
\text { Piedade 2010) }\end{array}$ & Terra firme forest & $\begin{array}{l}\text { Not formally } \\
\text { described }\end{array}$ & $\begin{array}{l}\text { Black water } \\
\text { seasonally flooded } \\
\text { forest, tahuampa } \\
\text { (Encarnación } \\
\text { 1985) }\end{array}$ & $\begin{array}{l}\text { Riparian } \\
\text { seasonally flooded } \\
\text { forest, gallery } \\
\text { forest }\end{array}$ & $\begin{array}{l}\text { Not formally } \\
\text { described }\end{array}$ & $\begin{array}{l}\text { Not formally } \\
\text { described }\end{array}$ \\
\hline \multicolumn{8}{|c|}{ Equivalent land-cover classes of Draper et al. (2014) } \\
\hline $\begin{array}{l}\text { Encompasses two } \\
\text { classes: open } \\
\text { peatland and pole } \\
\text { forest }\end{array}$ & Palm swamp & $\begin{array}{l}\text { Terra firme/ } \\
\text { occasionally } \\
\text { flooded forest }\end{array}$ & $\begin{array}{l}\text { Terra firme/ } \\
\text { occasionally } \\
\text { flooded forest }\end{array}$ & $\begin{array}{l}\text { Seasonally flooded } \\
\text { forest }\end{array}$ & $\begin{array}{l}\text { Seasonally flooded } \\
\text { forest }\end{array}$ & Palm swamp & Palm swamp \\
\hline
\end{tabular}

soil color was described as ranging from brown to black by respondents.

The relatively abundant and large cumala trees are used for construction, e.g., for the floors and walls of houses. One can also find the same small trees for roof structures that are characteristic of jiiris, in between the larger trees. Alaka is comparatively better hunting ground than jiiri, e.g., for tapirs, peccaries, lowland pacas, agoutis, coatis, sloths, and tortoises, as well as monkeys such as howler monkeys, squirrel monkeys, or monk sakis (see Table 1 for all scientific names), many of which are attracted by aguaje fruit and large trees more generally. It is also the ecosystem of choice for the harvesting of aguaje fruit and fiber, for commercialization and domestic textile production, respectively. During aguaje harvesting season, local people may visit alakas to cut aguaje palm trees and sell fruit to traveling traders. Urarina women gather seeds in alakas that they use for decoration and necklaces.

Because of the uses of alakas for hunting and harvesting of timber, fruit, and other nontimber forest products, interviewees generally attributed high importance to them and would regularly visit them. Not least, hunters would regularly have to cross alakas anyway, given that they surrounded the community where fieldwork took place.

\section{Atane}

This ecosystem is named after the Urarina word for "earth," which is atane. The defining feature of this ecosystem is the absence of prolonged flooding, i.e., beyond 1-2 days per year, or waterlogging of soils, in contrast to jiiri, alaka, and, to a lesser extent, elelia. The soil is usually brown, firm, and dry. If untouched, atane is generally covered in rain forest with large trees, but it is also the preferred location for setting up chacras, small-scale agricultural fields, and the communities themselves. Atane is close to synonymous with what is called restinga elsewhere in Peruvian Amazonia (Encarnación 1985), and many respondents used the two words interchangeably.

Atane is the most valuable ecosystem for the Urarina, as they grow their crops and build their houses in it. However, uncultivated atane areas are also highly valued as the best available hunting grounds. Many respondents suggested that "all animals can be found in atane," including all locally known monkey species; some further noteworthy game species are deer, peccaries, agoutis, and 
armadillos, as well as a variety of bird species, such as Spix's Guans, Grey-winged or Pale-winged Trumpeters, and Great Tinamous, which are less common in alaka and cannot usually be found in jiiris (see Table 1 for scientific names). Atane also offers the best variety of timber tree species for construction, including, but not limited to, cumala (i.e., Virola sp. or Iryanthera sp. of better quality than cumala from alaka), mahogany (Swietenia macrophylla, known as caoba in local Spanish), cedro (Cedrela odorata), marupá (Simarouba amara), copaiba (Copaifera officinalis), or capirona (Calycophyllum spruceanum). Older respondents noted a strong decline in the availability of these commercially valuable trees over the past few decades, although capirona could potentially be managed, as is already the case elsewhere in the Peruvian Amazon (Weber and Sotelo Montes 2005, Sotelo Montes et al. 2008).

Atane is considered a scarce and, in this sense, valuable ecosystem type among local community members. This was made clear in interviews when some respondents reported having to travel more than an hour to reach their chacras in an atane area. Furthermore, the search for atane motivated a move of the entire community about 25 years ago, as the previous location, about 30 minutes downstream by engine-powered canoe, or peque peque, did not offer enough atane for the growing population to build houses. Moving communities is a common practice among the Urarina, and although it is possible to protect houses from flooding by building them on stilts, the Urarina still exclusively choose to build communities in nonflooded, i.e., atane, areas, as Kramer (1979) noted 40 years ago. Indeed, a neighboring Urarina community had just moved to a different location shortly before we visited.

\section{Elelia}

The elelia ecosystem is dominated by the palm tree species locally known as shebón. Very likely, the name derives from the Urarina word for this palm tree, which is ele. In its appearance, elelia has similarities with alaka and atane, i.e., palm trees are mixed with other large trees, and elelia is only rarely flooded by river water. The soil ranges in color from brown to black and is less soft underfoot than in jiiri or alaka, probing being possible only to a depth of $20 \mathrm{~cm}$ (see Fig. 4). Although the soil is typically moist, standing water is much rarer than in alaka. Respondents noted that one cannot typically find aguaje in elelia, although other palm trees such as huasai or chonta (Euterpe precatoria) are present. The name elelia could be translated into Spanish as shebonal. Although the "sinky," wet ground is superficially similar to peatland ecosystems, and respondents mentioned elelia alongside jiiri and alaka as an example of "muddy" places, i.e., potential peatland areas, the examples of elelia that we visited had too thin an organic soil layer to be considered as peat forming.

Elelia is an important place for the harvesting of shebón leaves, which are used to cover the roofs of traditionally built houses. It is also a good hunting ground, where most game species can be found, similar to atane and alaka. Respondents mentioned monkeys, birds, agoutis, and tortoises, among others. Some female interviewees also said they could find seeds for decoration and necklaces in this ecosystem. Elelia can be found right next to the community, but overall, it appears to cover less area than the ecosystems described in the previous sections.

\section{Leuuaku}

The leuuaku ecosystem (see Fig. 5) shares many characteristics with atane, including the brown color of its soil, which is solid and dry when not flooded, as well as the vegetation cover consisting of mainly large trees, mixed with some shorter trees, and some palm trees. The main difference is that leuuaku is seasonally flooded by river water, because it is located at a lower topographic level than atane. In this sense, "seasonally flooded forest" might be an appropriate translation into English. In contrast to the atane ecosystem, renaco trees, i.e., large trees with aerial roots, such as Coussapoa sp. and Ficus sp., which are well adapted to seasonal flooding, can be found in leuuaku. Some interviewees mentioned that leuuaku is synonymous with what is called tahuampa elsewhere in the Peruvian Amazon, i.e., flooded forest, or alternatively, bajial, i.e., a low-lying area prone to flooding (Encarnación 1985). However, although very similar in meaning, these terms cannot be considered synonymous, because they miss the more fine-grained differences with the jierune ecosystem (see Urarina ecosystem classification: jierune). Furthermore, the term tahuampa is only applied to seasonally flooded forest when flooded (Encarnación 1985), whereas leuuaku is recognized as leuuaku even when not currently flooded. Because of the solid ground, it appears unlikely that the leuuaku ecosystem is typically peat forming, which agrees with the provisional view from the limited scientific surveys that peat-forming seasonally flooded forests, though not unknown, are rare in Peruvian Amazonia (Draper et al. 2014).

The main resources of leuuaku are fish, which are caught with traps when the area is under water and the fish can feed on fruit and seeds from flooded trees. Examples of common fish species found in leuuaku are shuyo (Hoplerythrinus unitaeniatus), sábalo (Brycon sp.), boquichico (Prochilodus nigricans), bujurqui (Biotodoma sp.), or palometa (Mylossoma duriventre). When not flooded, in a similar way to atane, leuuaku can be used for hunting. One can also find wood and timber, most importantly lagarto caspi (Calophyllum brasiliense), but also capirona and cumala, among others. Leuuaku is popular for collecting firewood, and no respondent considered this ecosystem to be unimportant.

\section{Jierune}

The jierune ecosystem can typically be found just next to rivers and streams. It is a low-lying area covered in thick vegetation of small trees and bushes and is seasonally flooded just like leuuaku. Some respondents had difficulties in specifying the differences between jierune and leuuaku, and others suggested that the name could be translated again as bajial or tahuampa (see Urarina ecosystem classification: leuuaku). Nevertheless, it appears that leuuaku and jierune are distinguished by their location (i.e., jierune is more likely to be located immediately next to a river) and vegetation physiognomy (i.e., jierune has much more dense vegetation with a much lower canopy, on average). Jierune may also contain some renacos, i.e., individual large trees with large aerial roots, and lianas, and one interviewee suggested that jierune could be translated as sogal, i.e., area where lianas grow.

Jierune is difficult to walk or hunt in because of the density of the vegetation; similarly, local people prefer putting fish traps in leuuaku, rather than jierune. Thus, it is less important in terms of resources than other ecosystems, which may also explain why some interviewees were reluctant to describe uses and detailed 
characteristics of this ecosystem. Nevertheless, jierune is a potential source for small trees that can be used for construction, especially roof structures, similar to jiiri.

\section{Kaiajurineeujua}

The kaiajurineeujua ecosystem is defined by an abundance of cumala trees (Virola sp. or Iryanthera sp.), called kaiajuri in Urarina. The suffix neeujua likely means "a lot" in this context. Beyond the abundance of cumala, kaiajurineeujua seems to be very similar to alaka; that is, it is a mix of large timber trees and palm trees, with dark and possibly "sucking", i.e., chupadera, ground. It is unclear whether kaiajurineeujua should be seen as an ecosystem type at the same hierarchical level as, for example, alaka, or whether it represents merely a slight floristic variation within alaka; it was reported by some respondents to be located "inside alaka." Nonetheless, the distinction is important to the local community because cumala appears to be the most popular timber tree species, used for house floors and walls and occasionally sold to traders. Most interviewees also readily translated kaiajurineeujua into local Spanish as cumalar, i.e., place where cumala trees grow. This ecosystem may be peat forming given the cited soil characteristics and overall similarity with alaka. However, it was not possible to visit a kaiajurineeujua during site visits. Like elelia, this ecosystem appears to cover only smaller areas.

\section{Ujuarineeujua}

The ujuarineeujua ecosystem is characterized by an abundance of huasai or chonta (Euterpe precatoria), called ujuari in Urarina. Again, respondents mentioned that it may be located "inside alaka"; that is, it is again unclear whether ujuarineeujua should be seen as a separate ecosystem or, rather, a subtype of alaka. The name could be translated as chontal into local Spanish. Overall, we do not have much information about ujuarineeujua, as respondents noted that it is not very common in the area. It was not mentioned during the participatory mapping workshop with the whole community at the beginning of our fieldwork, but rather in individual interviews with community members, and we were unable to visit it in person to verify its characteristics. Nevertheless, ujuari, or chonta, represents an important economic resource for local community members because it is harvested for its palm hearts and occasionally sold to visiting traders. In the study location, however, it appears that ujuari is mainly harvested from other ecosystems such as elelia, where individual palm trees of this species can be found.

\section{INTERPRETING INDIGENOUS PERSPECTIVES ON ECOSYSTEM CLASSIFICATION AND PEATLANDS}

Having presented an Urarina classification of the ecosystems of their surrounding environment in the preceding section, we connect our findings to broader academic debates. As outlined in the introduction, our findings may be of relevance to at least four broad themes, i.e., place naming, cultural heritage conservation, dialogue with scientific knowledge, and ecosystem management and conservation.

\section{Naming places and ecosystems}

Evidently, no single criterion is used in the Urarina ecosystem classification system to delimit the boundaries between various ecosystems. Important abiotic indicators include the hydrologic regime, e.g., to delimit the boundary between atane and leuuaku, and soils, which are the unifying feature across the various forms of jiiri. Topography matters in so far as it may determine flooding levels. Important biotic factors are individual palm tree species (aguaje, shebón, and chonta); the tree species cumala, which could be understood as "cultural keystone species" (Garibaldi and Turner 2004; see Interpreting indigenous perspectives on ecosystem classification and peatlands: cultural significance of tropical peatlands); but also vegetation physiognomy, e.g., because jierune is defined by shorter and denser vegetation than leuuaku.

Competing theories for the development of landscape terminology exist, which are likely to be relevant for ecosystem terminology more specifically as well. Levinson (2008), for example, suggests that perceptual salience of certain features, human uses, and cultural factors may all play a role (cultural factors are discussed subsequently). Clearly, all three factors are relevant, although it may sometimes be difficult to determine their relative importance. For example, jiiris are perceptually different through the reddish to black ground where one can only walk with great difficulty, as well as the comparatively lower height of the vegetation; however, they are also known as hunting grounds for caimans and tapirs and could in this way be interpreted as a resource area. Similarly, the main difference between atane and leuuaku is the presence of seasonal flooding in the latter, but leuuaku is also known for the abundance of fish as a specific resource that can be caught with traps when flooded. Thus, salience and human uses are closely interwoven.

Conversely, elelia, kaiajurineeujua, and ujuarineeujua are primarily known as specific places to locate a certain natural resource and, in this sense, could be interpreted as "resource islands" embedded in the broader environment, such as, e.g., "the forest" (Posey 1985, Gilmore et al. 2013). Their simple definition as a "place where dominant resource plant species $X$ can be found" is similar to naming conventions elsewhere in the Amazon, as reported by, e.g., Wartmann and Purves (2018), who also found that a large number of indigenous ecosystem types were named after a single plant species. This is in fact similar to naming practices in the English language, too, where one may speak of, e.g., "oak forest" or "beech forest."

\section{Cultural significance of tropical peatlands}

As Levinson (2008) noted, cultural factors may also play a significant role in developing classificatory systems for landscapes and ecosystems. We place special emphasis on the cultural significance of peatland areas, an understudied field of research across tropical climate zones. Furthermore, this aspect of the research also contributes to documenting a relevant aspect of Urarina culture that might be at risk of being lost through cultural assimilation, this documentation and "safeguarding" being the objective of much research on indigenous knowledge (Shepard et al. 2001, Hance 2015, Ens et al. 2016).

As is common elsewhere in the Amazon, the Urarina traditionally believe in mythical creatures, spirits, "mothers," or owners that inhabit certain ecosystems (Kamppinen 1988, Larochelle 2012, Comberti et al. 2015, Smith 2015, Burton 2018). For example, the "mother" of the leuuaku is said to be an anaconda. These spirits have supernatural powers and are typically feared for their evil character and tricks, but they are also seen as "defenders" of their particular ecosystem. In this way, they may serve as deterrents for environmentally unsustainable behavior, e.g., overharvesting of natural resources or hunting (Larochelle 2012, Burton 2018). 
Interestingly, one such "mother" or spirit recognized by the Urarina, the Baainu, lives in both alaka and jiiri ecosystems, i.e., the two main ecosystems that are most likely peatland ecosystems. As many interviewees testified, the Baainu may make people lose their way in the jiiri and alaka by calling an unlucky person's name, disguising its voice, and pretending to be a family member. Ultimately, the Baainu seeks to transform the (human) person into a Baainu. The Baainu may also steal items from hunters, such as machetes. The name Baainu might be related to witchcraft, given that Dean (1999) translates the word bainee as "sorcery." The Baainu's strategy was told to us as follows by one community member:

Sometimes, when the Baainu wants to take you, and you are following some animal, such as a white or black monkey, he will confuse you and you follow the animal, thinking that you're going a short distance, when actually, it is not. "Where is it?" you start wondering. Jiiri and alaka have the same mother, and he [i.e., the motherl Baainu who is both male and female] takes you to his very nice house, the pillars of which are built with the trunk of an aguaje palm tree. Under it, you can see aguaje fruit that he will eat. There are also white monkeys sitting on both shoulders of the mother, and an animal that looks like a jaguar can be seen, too, chained and with its mouth well tied up. Your family members will be looking for you, but the Baainu will tell you not to listen to the noise and he will confuse you. You will see a beautiful house, nice houses, and it does not appear muddy. You can feel that there is a good soil, and the houses look really very nice. The animal from the Baainu's shoulder will want to jump on your shoulder and sit there; but if it does jump and sits on your shoulder, you will never see your relatives ever again. Your family will look for you and for someone who knows how to drink ayahuasca, and through that $[i$. e., drinking ayahuasca ], the Baainu will say: "Before I make you eat with these animals, I will take you to your house, so you can go home. I don't like it when they call me like this." Having said that, he will take you and put you back to the place where he found you. [...] But if your family does not search for you, well, then you will stay there forever.

Not all interviewees were willing to answer questions about the Baainu, and some stated that they had no knowledge of it; this reluctance to respond or loss of knowledge may potentially be related to the loss of traditional belief systems or their replacement with evangelical Christian beliefs, introduced by Argentinean and U.S. missionaries (Olawsky 2006). In other cases, people may have not been willing to share their personal beliefs with a stranger. The Baainu story has many similarities with the traditional belief in the Chullachaqui across Amazonia, an evil spirit that makes people lose their way by taking up the appearance of a different person (Larochelle 2012, Smith 2015), known by many different names (Burton 2018). In contrast to the Baainu, however, the Chullachaqui is known as the "guardian spirit of the forest" (Larochelle 2012), i.e., it is not usually associated with palm swamp and peatland ecosystems such as jiiri and alaka. The Maijuna of the Peruvian Amazon do know an evil spirit that lives in palm swamps, the Gogobai, who may abduct local people (Gilmore et al. 2013). However, the Gogobai aims to eat its victims, which is not the case for the Baainu. Thus, each mythological figure has some unique features, and descriptions even for the same spirit may vary between people and communities (see also Walker 2013b). This suggests that indigenous knowledge is not "fixed," and that there is a contrast not only between indigenous and scientific knowledge but also between various indigenous knowledges, i.e., between different indigenous peoples, as well as within one indigenous nation. In this sense, indigenous knowledge should be seen in relational terms, rather than space bound and clearly defined (Andolina et al. 2009). It also implies that our description of the cultural heritage, as well as of the Urarina ecosystem categories themselves, can always only be an approximation or simplification of the diversity of indigenous knowledges.

Beyond the Baainu spirit of jiiri and alaka, peatland areas have further special cultural significance to the Urarina, given that they are the source of aguaje palm tree fiber, which Urarina women use for the production of traditional textiles, known as cachihuango elsewhere in the Peruvian Amazon (Morales Chocano 2004). These textiles are of central importance to Urarina culture and cosmology, and in this way, aguaje could be understood as a "cultural keystone species," given the central importance of this species for both ecology and culture in the area (Garibaldi and Turner 2004). Dean (1994) recounts the Urarina creation myth, which involves an episode in which the distinction between "ignorant" and "wise" women is described as their ability to make palm-fiber cloth. The practice of weaving these palmfiber cloths continues today, even if most Urarina women now wear clothes made from cotton.

\section{Lessons learned for ecology and conventional science}

The Urarina ecosystem classification gives valuable insights and inspiration for further scientific research, and in this way, it can serve as a reference framework for comparison, ground truthing, and learning, as noted by many ethnoecologists (Fleck and Harder 2000, Shepard et al. 2001, Abraão et al. 2008, FernándezLlamazares et al. 2017, Reyes-García et al. 2018). Scientific description and mapping of the vegetation of Peruvian Amazonia is an active field of research. Community ecologists recognize that vegetation classifications are necessarily a simplification of reality, but they are widely used for pragmatic purposes. Various terms for different categories of vegetation or landscape units have been introduced into the literature (see examples in Table 2), usually informally, with different classification schemes developed for different purposes. One example is the large-scale mapping of Draper et al. (2014) aimed at identifying vegetation associated with peat and hence at modeling the distribution of above- and belowground carbon storage. It used a simple sevenfold classification of land-cover types, i.e., terra firme/ occasionally flooded forest, seasonally flooded forest, open peatland, peatland pole forest, palm swamp, bare ground, and open water, which focuses on reflectance properties that are visible in optical satellite imagery and on hydrologic properties that can be inferred from satellite-based radar data. Draper et al. (2018) later showed that distinctions between peatland pole forest, palm swamp, and terra firme forest, defined in the same way, are supported by floristic survey data; that is, the species composition of each vegetation type is substantially different. It would be highly desirable to carry out similar floristic inventories in the various ecosystems identified by the Urarina, which would 
potentially be another opportunity for learning from indigenous environmental knowledge (see also Abraão et al. 2008).

Comparison of the terms used by Draper et al. $(2014,2018)$ and the Urarina (Table 2) suggests both similarities and differences. The Urarina appear to consider both "open peatlands" and "peatland pole forest" to be constituents of jiiri, perhaps because the structural mix of herbs, shrubs, and trees shows rather continuous variation and because the types of resources, such as caiman and tapirs, found throughout the jiiri are the same. From a scientific point of view, the ecological and floristic relationships between open peatlands and peatland pole forests remain an open question: To our knowledge, no formal botanical description of an open peatland has yet been undertaken, and it is not yet clear whether the two (possibly end-member) environments typically form part of a temporal succession or some other kind of physical or chemical gradient. Conversely, our interviewees named two subcategories of palm swamp, kaiajurineeujua and ujuarineeujua, which are characterized by particular tree species that are important resources to them. The prevailing scientific classification risks playing down the significance of the swamp forests for the people who rely on them for their subsistence. The Urarina ecosystem classification explicitly incorporates human ecology and is in this sense more holistic than current scientific classification systems as is often the case in indigenous or traditional ecosystem classifications (Berkes et al. 1998).

The terms "open peatland" and "peatland pole forest," increasingly important in the scientific literature on carbon storage, do not have direct equivalents in the Urarina language, which poses a challenge for scientists in communicating with local community members. However, it is also interesting that although peat itself does not have any local uses, unlike in northern countries such as Scotland or Finland, it seems that the boundary between jiiri and alaka on the one hand, and other ecosystem types on the other, does indeed coincide with the presence of peat in the ground. Further interdisciplinary research would be desirable to establish whether there is such a link between indigenous knowledge and scientific understanding of soils.

\section{Ecosystem management, conservation, and socioeconomic} development implications

As many scholars have noted, studying indigenous knowledge may contribute to better ecosystem management and environmental conservation (Stevenson 1996, Berkes et al. 2000, Chapin 2004, Folke 2004, Sheil and Lawrence 2004, Puri 2007 , Sileshi et al. 2009). On a very basic level, learning an indigenous terminology may help with communication across cultural and epistemological differences (Omotayo and Musa 1999). Any outside actor engaging in environmental management and conservation activities in Urarina territory will benefit from understanding that the community has a sophisticated view of its own environment, reflecting the value of the many resources that the community uses through local ways of classifying the environment, and that it does not see the environment in exactly the same way as scientists or development workers schooled in a different tradition. Better communication between outsiders and local communities may make for more effective collaborations, with community priorities and aspirations better recognized from the outset and scientists better able to translate their ideas into mutually intelligible terms (Ens et al. 2016). There may also be connections between spatial and temporal aspects, i.e., indigenous ecosystems and aspects of seasonality, or phenology, e.g., in the form of seasonal fishing activities in the leuuaku or harvesting calendars for particular resources, with potential implications for environmental management and adaptation to environmental change (Davidson-Hunt and Berkes 2003, Gómez-Baggethun et al. 2013, Armatas et al. 2016).

Our work has shown that much of Urarina culture is intimately linked to their environment. Myths, legends, and stories about the different ecosystems, such as the Baainu described previously, or the notion that certain plant species have "owners" or "mothers," i.e., guardian spirits, which pose a threat to humans, but which, if respected, indirectly help with the conservation of natural resources (see Interpreting indigenous perspectives on ecosystem classification and peatlands: cultural significance of tropical peatlands), are shared, to a varying extent, among members of the community and thus are part of their social identity. This brings a human dimension to the landscape that is currently lacking from the literature on biodiversity and carbon conservation on Amazonian peatlands (Roucoux et al. 2017), although it has previously been noted that indigenous ecosystem classifications are often better suited to capture social-ecological dynamics than conventional ecology (Berkes et al. 1998). If we value diversity in human culture, the strong link between Urarina culture and their environment provides an additional reason for conserving, or at least carefully managing development in, Amazonia's wetland environments.

The apparent respect for jiiri and alaka evidenced by their "ambiguous" cultural position, i.e., valued but also feared, suggests that there may be synergies between cultural protection and biodiversity and carbon conservation. In the current context of calls to vastly increase the scope of protected areas that limit or even exclude people (Wilson 2016), it is important that future research engages actively with the communities living in these areas. This is especially important in quantitative studies that aim to address how biodiversity and carbon stocks are affected by the presence and activities of indigenous and more recent settler communities. Emphasizing their voices in these studies will help strengthen their own management of diverse peatland-rich environments.

\section{CONCLUSIONS}

We have established the importance of taking indigenous ecosystem classification systems seriously in academic debates on tropical peatlands by showing how Urarina indigenous communities living in Peruvian Amazonia classify their peatlandrich and wetland-dominated environment. We found that the Urarina recognize at least 8 ecosystem types, which are defined by multiple biotic indicators, such as salient tree species and vegetation physiognomy, and abiotic indicators, such as hydrology, topography, and soils. This suggests that the Urarina do not place as much emphasis on single-species-defined ecosystems as other indigenous peoples in Amazonia, who distinguish 40 to 60 such ecosystems (e.g., Shepard et al. 2001, Wartmann and Purves 2018). Compared with existing scientific classification schemes, which are so far mostly based on floristic composition and vegetation structure (Draper et al. 2014, 2018), the Urarina ecosystems are more holistic and include human ecology as well. 
This knowledge could potentially be used for communication between scientists and local people, as well as for improved environmental management and conservation. It could also be the basis for further participatory mapping exercises, including participatory GIS (Chapin et al. 2005, Olson et al. 2016) and detailed vegetation surveys in the various Urarina ecosystems, to gain a better understanding of the spatial aspects of the various ecosystems and traditional land uses and how they compare with existing remote-sensing-based maps and ecological classifications (i.e., Draper et al. 2014, 2018).

Two Urarina ecosystems, jiiri and alaka, appear to be peatlands and, moreover, hold a central position in Urarina culture as the home of the mythical creature called Baainu, which may trick and trap people who may get lost in the difficult terrain. Culturally, peatlands thus occupy an ambiguous position for the Urarina, because they are not only dangerous places but also places for hunting caimans and tapirs, where the commercially valuable aguaje fruit can be harvested, and where women can find aguaje fiber to produce traditional textiles. In this way, tropical peatlands may be similar to peatlands in European countries, which are also perceived as culturally ambivalent spaces (Lehtinen 2000, Byg et al. 2017). This may suggest that the particular geography of peatlands may shape human perceptions across cultural and climatic boundaries.

Describing an Urarina classification system also opens up the possibility to use these categories in future scientific research that aims to close some of the existing gaps that we have exposed. Abraão et al. (2008) have noted that already Amazonian ecosystem classification borrows heavily from local terms (e.g., Encarnación 1985). Jiiri and alaka could potentially become scientifically defined terms, in this way demonstrating that indeed boundaries between indigenous and scientific knowledge are arbitrary, and that the two can often complement each other very well.

Responses to this article can be read online at: http://www.ecologyandsociety.org/issues/responses. php/10886

\section{Acknowledgments:}

The authors would like to thank the community of Nueva Unión, Loreto, Peru, for participating in this research. Particular thanks go to Samuel Nuribe for confirming Urarina spellings for this article. We would also like to thank Michael Gilmore for advice on participatory mapping, and Harry Walker for advice on doing research in Urarina communities. Thanks are also due to Eurídice Honorio Coronado, Tim Baker, Jhon del Aguila Pasquel, Gabriel Hidalgo, and Marcos Ríos for advice on the ecology of the area, Greta Dargie for advice on peat and peatland characteristics, and Freddie Draper for access to data. We gratefully acknowledge funding from the Scottish Funding Council, the Natural Environment Research Council (NE/R000751/1), and the University of St Andrews.

\section{LITERATURE CITED}

Abraão, M. B., B. W. Nelson, J. C. Baniwa, D. W. Yu, and G. H. Shepard, Jr. 2008. Ethnobotanical ground-truthing: indigenous knowledge, floristic inventories and satellite imagery in the upper Rio Negro, Brazil. Journal of Biogeography 35(12):2237-2248. https://doi.org/10.1111/j.1365-2699.2008.01975.x

Agrawal, A. 1995. Dismantling the divide between indigenous and scientific knowledge. Development and Change 26(3):413-439. https://doi.org/10.1111/j.1467-7660.1995.tb00560.x

Agrawal, A. 2009. Why "indigenous" knowledge? Journal of the Royal Society of New Zealand 39(4):157-158. https://doi. org/10.1080/03014220909510569

Andolina, R., N. Laurie, and S. A. Radcliffe. 2009. Indigenous development in the Andes: culture, power, and transnationalism. Duke University Press, Durham, North Carolina, USA. https:// doi.org/10.1215/9780822391067

Armatas, C. A., T. J. Venn, B. B. McBride, A. E. Watson, and S. J. Carver. 2016. Opportunities to utilize traditional phenological knowledge to support adaptive management of social-ecological systems vulnerable to changes in climate and fire regimes. Ecology and Society 21(1):16. https://doi.org/10.5751/ES-07905-210116

Balslev, H., C. Grandez, N. Y. Paniagua Zambrana, A. L. Møller, and S. L. Hansen. 2008. Palmas (Arecaceae) útiles en los alrededores de Iquitos, Amazonía Peruana. Revista Peruana de Biología 15(3):121-132. https://doi.org/10.15381/rpb.v15i3.3343

Berkes, F., J. Colding, and C. Folke. 2000. Rediscovery of traditional ecological knowledge as adaptive management. Ecological Applications 10(5):1251-1262. https://doi.org/10.1890/1051-0761 (2000)010[1251:ROTEKA]2.0.CO;2

Berkes, F., M. Kislalioglu, C. Folke, and M. Gadgil. 1998. Exploring the basic ecological unit: ecosystem-like concepts in traditional societies. Ecosystems 1(5):409-415. https://doi. org/10.1007/s100219900034

Burton, A. 2018. Who's afraid of the Curupira? Frontiers in Ecology and the Environment 16(5):308. https://doi.org/10.1002/ fee. 1817

Byg, A., J. Martin-Ortega, K. Glenk, and P. Novo. 2017. Conservation in the face of ambivalent public perceptions - the case of peatlands as 'the good, the bad and the ugly.' Biological Conservation 206:181-189. https://doi.org/10.1016/j.biocon.2016.12.022

Cajas Rojas, J., A. Corbera, B. Gualdieri, and G. Solis. 1987. Bibliografía etnolingüística urarina. Instituto de Lingüística Aplicada (CILA), Universidad Nacional Mayor de San Marcos, Lima, Peru.

Chapin, M. 2004. A challenge to conservationists. World Watch 17(6):17-31. [online] URL: http://www.worldwatch.org/node/565

Chapin, M., Z. Lamb, and B. Threlkeld. 2005. Mapping indigenous lands. Annual Review of Anthropology 34:619-638. https://doi.org/10.1146/annurev.anthro.34.081804.120429

Comberti, C., T. F. Thornton, V. Wyllie de Echeverria, and T. Patterson. 2015. Ecosystem services or services to ecosystems? Valuing cultivation and reciprocal relationships between humans and ecosystems. Global Environmental Change 34:247-262. https:// doi.org/10.1016/j.gloenvcha.2015.07.007 
Couwenberg, J., R. Dommain, and H. Joosten. 2010. Greenhouse gas fluxes from tropical peatlands in south-east Asia. Global Change Biology 16(6):1715-1732. https://doi.org/10.1111/ j.1365-2486.2009.02016.x

Dargie, G. C., S. L. Lewis, I. T. Lawson, E. T. A. Mitchard, S. E. Page, Y. E. Bocko, and S. A. Ifo. 2017. Age, extent and carbon storage of the central Congo Basin peatland complex. Nature 542 (7639):86-90. https://doi.org/10.1038/nature21048

Davidson-Hunt, I., and F. Berkes. 2003. Learning as you journey: Anishinaabe perception of social-ecological environments and adaptive learning. Conservation Ecology 8(1):5. https://doi. org/10.5751/ES-00587-080105

Dean, B. 1994. The poetics of creation: Urarina cosmogony and historical consciousness. Latin American Indian Literatures Journal 10(1):22-45.

Dean, B. 1999. Intercambios ambivalentes en la Amazonia: formación discursiva y la violencia del patronazgo. Anthropologica 17(17):85-115. [online] URL: http://revistas.pucp. edu.pe/index.php/anthropologica/article/view/1539

Dean, B. 2009. Urarina society, cosmology, and history in Peruvian Amazonia. University of Florida Press, Gainesville, Florida, USA. https://doi.org/10.5744/florida/9780813033785.001.0001

Delgado, C., G. Couturier, and K. Mejia. 2007. Mauritiaflexuosa (Arecaceae: Calamoideae), an Amazonian palm with cultivation purposes in Peru. Fruits 62(3):157-169. https://doi.org/10.1051/ fruits:2007011

Díaz Barba, A. 1987. La chawa de chacra urarina. Una técnica tradicional de agricultura amazónica. Boletín de Lima 49:65-72.

Draper, F. C., E. N. Honorio Coronado, K. H. Roucoux, I. T. Lawson, N. C. A. Pitman, P. V. A. Fine, O. L. Phillips, L. A. Torres Montenegro, E. Valderrama Sandoval, I. Mesones, R. GarcíaVillacorta, F. R. Ramirez Arévalo, and T. R. Baker. 2018. Peatland forests are the least diverse tree communities documented in Amazonia, but contribute to high regional beta-diversity. Ecography 41(8):1256-1269. https://doi.org/10.1111/ecog.03126

Draper, F. C., K. H. Roucoux, I. T. Lawson, E. T. A. Mitchard, E. N. Honorio Coronado, O. Lähteenoja, L. Torres Montenegro, E. Valderrama Sandoval, R. Zárate, and T. R. Baker. 2014. The distribution and amount of carbon in the largest peatland complex in Amazonia. Environmental Research Letters 9 (12):124017. https://doi.org/10.1088/1748-9326/9/12/124017

Duvall, C. S. 2008. Classifying physical geographic features: the case of Maninka farmers in southwestern Mali. Geografiska Annaler: Series B, Human Geography 90(4):327-348. https://doi. org/10.1111/j.1468-0467.2008.00297.x

Encarnación, F. 1985. Introducción a la flora y la vegetación de la Amazonía peruana: estado actual de los estudios, medio natural y ensayo de una clave de determinación de las formaciones vegetales en la llanura amazónica. Candollea 40(1):237-252.

Ens, E., M. L. Scott, Yugul Mangi Rangers, C. Moritz, and R. Pirzl. 2016. Putting indigenous conservation policy into practice delivers biodiversity and cultural benefits. Biodiversity and Conservation 25(14):2889-2906. https://doi.org/10.1007/s10531-016-1207-6
Fabiano, E. 2015. "Le corps mange, tout comme la pensée soigne". construction des corps et techniques de contamination dans la pratique chamanique Urarina. Dissertation. École des Hautes Études en Sciences Sociales (EHESS), Paris, France.

Fernández-Llamazares, Á., R. Amaral Garcia, I. Díaz-Reviriego, M. Cabeza, A. Pyhälä, and V. Reyes-García. 2017. An empirically tested overlap between indigenous and scientific knowledge of a changing climate in Bolivian Amazonia. Regional Environmental Change 17(6):1673-1685. https://doi.org/10.1007/s10113-017-1125-5

Fleck, D. W., and J. D. Harder. 2000. Matses Indian rainforest habitat classification and mammalian diversity in Amazonian Peru. Journal of Ethnobiology 20(1):1-36. [online] URL: https:// ethnobiology.org/sites/default/files/pdfs/JoE/20-1/FleckHarder.pdf

Folke, C. 2004. Traditional knowledge in social-ecological systems. Ecology and Society 9(3):7. https://doi.org/10.5751/ ES-01237-090307

Freitas Alvarado, L., E. Otárola Acevedo, D. del Castillo Torres, C. Linares Bensimón, P. Martínez Dávila, and G. A. Malca Salas. 2006. Servicios ambientales de almacenamiento y secuestro de carbono del ecosistema aguajal en la Reserva Nacional Pacaya Samiria, Loreto - Perú. Documento Técnico No. 29, Instituto de Investigaciones de la Amazonía Peruana, Iquitos, Peru. [online] URL: http://repositorio.iiap.org.pe/handle/IIAP/228

Garibaldi, A., and N. Turner. 2004. Cultural keystone species: implications for ecological conservation and restoration. Ecology and Society 9(3):1. https://doi.org/10.5751/ES-00669-090301

Gilmore, M. P., B. A. Endress, and C. M. Horn. 2013. The sociocultural importance of Mauritia flexuosa palm swamps (aguajales) and implications for multi-use management in two Maijuna communities of the Peruvian Amazon. Journal of Ethnobiology and Ethnomedicine 9:29. https://doi. org/10.1186/1746-4269-9-29

Gómez-Baggethun, E., E. Corbera, and V. Reyes-García. 2013. Traditional ecological knowledge and global environmental change: research findings and policy implications. Ecology and Society 18(4):72. https://doi.org/10.5751/ES-06288-180472

Hance, J. 2015. Amazon tribe creates 500-page traditional medicine encyclopedia. Mongabay, 24 June. [online] URL: https:// news.mongabay.com/2015/06/amazon-tribe-creates-500-page-traditionalmedicine-encyclopedia/

Hunn, E. 1996. Columbia Plateau Indian place names: what can they teach us? Journal of Linguistic Anthropology 6(1):3-26. https://doi.org/10.1525/ilin.1996.6.1.3

Johnson, L. M., and I. Davidson-Hunt. 2011. Ethnoecology and landscapes. Pages 267-284 in E. N. Anderson, D. Pearsall, E. Hunn, and N. Turner, editors. Ethnobiology. Wiley-Blackwell, Hoboken, New Jersey, USA. https://doi.org/10.1002/9781118015872. $\underline{\operatorname{ch} 16}$

Junk, W. J., and M. T. F. Piedade. 2010. An introduction to South American wetland forests: distribution, definitions and general characterization. Pages 3-25 in W. J. Junk, M. T. F. Piedade, F. Wittmann, J. Schöngart, and P. Parolin, editors. Amazonian floodplain forests: ecophysiology, biodiversity and sustainable 
management. Springer, Dordrecht, The Netherlands. https://doi. org/10.1007/978-90-481-8725-6_1

Kamppinen, M. 1988. Espiritus incorporados: the roles of plants and animals in the Amazonian mestizo folklore. Journal of Ethnobiology 8(2):141-148. [online] URL: https://ethnobiology. org/sites/default/files/pdfs/JoE/8-2/Kamppinen1988.pdf

Koh, L. P., R. A. Butler, and C. J. A. Bradshaw. 2009. Conversion of Indonesia's peatlands. Frontiers in Ecology and the Environment 7(5):238. https://doi.org/10.1890/09.WB.013

Kramer, B. J. 1977. Las implicaciones ecológicas de la agricultura de los Urarina. Amazonía Peruana 1:75-86.

Kramer, B. J. 1979. Urarina economy and society: tradition and change. Dissertation. Columbia University, New York, New York, USA.

Lähteenoja, O., Y. Rojas Reátegui, M. Räsänen, D. del Castillo Torres, M. Oinonen, and S. Page. 2012. The large Amazonian peatland carbon sink in the subsiding Pastaza-Marañón foreland basin, Peru. Global Change Biology 18(1):164-178. https://doi. org/10.1111/j.1365-2486.2011.02504.X

Lähteenoja, O., K. Ruokalainen, L. Schulman, and J. Alvarez. 2009. Amazonian floodplains harbour minerotrophic and ombrotrophic peatlands. Catena 79(2):140-145. https://doi. org/10.1016/j.catena.2009.06.006

Larochelle, J. 2012. Writing under the shadow of the Chullachaqui: Amazonian thought and ecological discourse in recent Amazonian poetry. Review: Literature and Arts of the Americas 45(2):198-206. https://doi.org/10.1080/08905762.2012.719773

Lawson, I. T., T. J. Kelly, P. Aplin, A. Boom, G. Dargie, F. C. H. Draper, P. N. Z. B. P. Hassan, J. Hoyos-Santillan, J. Kaduk, D. Large, W. Murphy, S. E. Page, K. H. Roucoux, S. Sjögersten, K. Tansey, M. Waldram, B. M. M. Wedeux, and J. Wheeler. 2015. Improving estimates of tropical peatland area, carbon storage, and greenhouse gas fluxes. Wetlands Ecology and Management 23 (3):327-346. https://doi.org/10.1007/s11273-014-9402-2

Leach, M., and J. Fairhead. 2002. Manners of contestation: "citizen science" and "indigenous knowledge" in West Africa and the Caribbean. International Social Science Journal 54 (173):299-311. https://doi.org/10.1111/1468-2451.00383

Lehtinen, A. A. 2000. Mires as mirrors. Peatlands - hybrid landscapes of the North. Fennia 178(1):125-137.

Levinson, S. C. 2008. Landscape, seascape and the ontology of places on Rossel Island, Papua New Guinea. Language Sciences 30(2-3):256-290. https://doi.org/10.1016/j.langsci.2006.12.032

Löfmarck, E., and R. Lidskog. 2017. Bumping against the boundary: IPBES and the knowledge divide. Environmental Science \& Policy 69:22-28. https://doi.org/10.1016/j.envsci.2016.12.008

Ludwig, D. 2016. Overlapping ontologies and Indigenous knowledge. From integration to ontological self-determination. Studies in History and Philosophy of Science Part A 59:36-45. https://doi.org/10.1016/j.shpsa.2016.06.002

Ludwig, D. 2017. The objectivity of local knowledge. Lessons from ethnobiology. Synthese 194(12):4705-4720. https://doi. org/10.1007/s11229-016-1210-1
Manus, P. 1992. Proposiciones de desarrollo y de apoyo y su expresión en las oraciones del urarina. Revista Latinoamericana de Estudios Etnolingüísticos 7:15-45.

Molnár, Z. 2013. Traditional vegetation knowledge of the Hortobágy salt steppe (Hungary): a neglected source of information for vegetation science and conservation. Phytocoenologia 43(3-4):193-205. https://doi.org/10.1127/0340-269X/2013/0043-0561

Morales Chocano, D. 2004. Los urarinas de la Amazonía: un modelo sustentable de subsistencia. Investigaciones Sociales 8 (13):43-71. https://doi.org/10.15381/is.v8i13.6916

O’Flaherty, R. M., I. J. Davidson-Hunt, and M. Manseau. 2008. Indigenous knowledge and values in planning for sustainable forestry: Pikangikum First Nation and the Whitefeather Forest Initiative. Ecology and Society 13(1):6. https://doi.org/10.5751/ ES-02284-130106

Olawsky, K. J. 2002. Urarina texts. Languages of the World/Text Collections 17. LINCOM, Munich, Germany.

Olawsky, K. J. 2006. A grammar of Urarina. Mouton de Gruyter, Berlin, Germany. https://doi.org/10.1515/9783110892932

Olson, R., J. Hackett, and S. DeRoy. 2016. Mapping the digital terrain: towards indigenous geographic information and spatial data quality indicators for indigenous knowledge and traditional land-use data collection. Cartographic Journal 53(4):348-355. https://doi.org/10.1080/00087041.2016.1190146

Omotayo, A., and M. W. Musa. 1999. The role of indigenous land classification and management practices in sustaining land use system in the semi-arid zone of Nigeria. Journal of Sustainable Agriculture 14(1):49-58. https://doi.org/10.1300/J064v14n01 05

Pascual, U., P. Balvanera, S. Díaz, G. Pataki, E. Roth, M. Stenseke, R. T. Watson, E. Başak Dessane, M. Islar, E. Kelemen, V. Maris, M. Quaas, S. M. Subramanian, H. Wittmer, A. Adlan, S. E. Ahn, Y. S. Al-Hafedh, E. Amankwah, S. T. Asah, P. Berry, A. Bilgin, S. J. Breslow, C. Bullock, D. Cáceres, H. Daly-Hassen, E. Figueroa, C. D. Golden, E. Gómez-Baggethun, D. GonzálezJiménez, J. Houdet, H. Keune, R. Kumar, K. Ma, P. H. May, A. Mead, P. O'Farrell, R. Pandit, W. Pengue, R. Pichis-Madruga, F. Popa, S. Preston, D. Pacheco-Balanza, H. Saarikoski, B. B. Strassburg, M. van den Belt, M. Verma, F. Wickson, and N. Yagi. 2017. Valuing nature's contributions to people: the IPBES approach. Current Opinion in Environmental Sustainability 26-27:7-16. https://doi.org/10.1016/j.cosust.2016.12.006

Pereira, P., E. C. Brevik, M. Oliva, F. Estebaranz, D. Depellegrin, A. Novara, A. Cerdà, and O. Menshov. 2017. Goal oriented soil mapping: applying modern methods supported by local knowledge. Pages 61-83 in P. Pereira, E. C. Brevik, M. MuñozRojas, and B. A. Miller, editors. Soil mapping and process modeling for sustainable land use management. Elsevier, Amsterdam, The Netherlands. https://doi.org/10.1016/B978-0-12-805200-6.00003-7

Posey, D. A. 1985. Indigenous management of tropical forest ecosystems: the case of the Kayapó Indians of the Brazilian Amazon. Agroforestry Systems 3(2):139-158. https://doi. org/10.1007/BF00122640 
Puri, S. K. 2007. Integrating scientific with indigenous knowledge: constructing knowledge alliances for land management in India. MIS Quarterly 31(2):355-379. https://doi.org/10.2307/25148795

Rainey, S. J. 2005. Folk classification and capability assessment of soils in two highland Guatemalan municipios. Journal of Latin American Geography 4(1):77-106. https://doi.org/10.1353/ lag.2005.0026

Raymond, C. M., I. Fazey, M. S. Reed, L. C. Stringer, G. M. Robinson, and A. C. Evely. 2010. Integrating local and scientific knowledge for environmental management. Journal of Environmental Management 91(8):1766-1777. https://doi.org/10.1016/ j.jenvman.2010.03.023

Reyes-García, V., Á. Fernández-Llamazares, M. Guèze, and S. Gallois. 2018. Does weather forecasting relate to foraging productivity? An empirical test among three hunter-gatherer societies. Weather, Climate, and Society 10(1):163-177. https://doi. org/10.1175/WCAS-D-17-0064.1

Robbins, P. 2003. Beyond ground truth: GIS and the environmental knowledge of herders, professional foresters, and other traditional communities. Human Ecology 31(2):233-253. https://doi.org/10.1023/A:1023932829887

Roucoux, K. H., I. T. Lawson, T. R. Baker, D. Del Castillo Torres, F. C. Draper, O. Lähteenoja, M. P. Gilmore, E. N. Honorio Coronado, T. J. Kelly, E. T. A. Mitchard, and C. F. Vriesendorp. 2017. Threats to intact tropical peatlands and opportunities for their conservation. Conservation Biology 31(6):1283-1292. https:// doi.org/10.1111/cobi.12925

Sheil, D., and A. Lawrence. 2004. Tropical biologists, local people and conservation: new opportunities for collaboration. Trends in Ecology and Evolution 19(12):634-638. https://doi.org/10.1016/j. tree.2004.09.019

Shepard, G. H., Jr., D. W. Yu, M. Lizarralde, and M. Italiano. 2001. Rain forest habitat classification among the Matsigenka of the Peruvian Amazon. Journal of Ethnobiology 21(1):1-38. [online] URL: https://ethnobiology.org/sites/default/files/pdfs/ JoE/21-1/Shepard-etal.pdf

Sileshi, G. W., P. Nyeko, P. O. Y. Nkunika, B. M. Sekematte, F. K. Akinnifesi, and O. C. Ajayi. 2009. Integrating ethno-ecological and scientific knowledge of termites for sustainable termite management and human welfare in Africa. Ecology and Society 14(1):48. https://doi.org/10.5751/ES-02877-140148

Smith, N. 2015. Palms and people in the Amazon. Springer International, Cham, Switzerland. https://doi.org/10.1007/978-3-319-05509-1

Smith, B., and D. M. Mark. 2003. Do mountains exist? Towards an ontology of landforms. Environment and Planning B: Planning and Design 30(3):411-427. https://doi.org/10.1068/b12821

Sotelo Montes, C., R. E. Hernández, J. Beaulieu, and J. C. Weber. 2008. Genetic variation in wood color and its correlations with tree growth and wood density of Calycophyllum spruceanum at an early age in the Peruvian Amazon. New Forests 35(1):57-73. https://doi.org/10.1007/s11056-007-9060-9
Steele, M. Z., and C. M. Shackleton. 2010. Using local experts as benchmarks for household local ecological knowledge: scoring in South African savannas. Journal of Environmental Management 91(8):1641-1646. https://doi.org/10.1016/j.jenvman.2010.02.031

Stevenson, M. G. 1996. Indigenous knowledge in environmental assessment. Arctic 49(3):278-291. https://doi.org/10.14430/ $\underline{\operatorname{arctic} 1203}$

Tengö, M., R. Hill, P. Malmer, C. M. Raymond, M. Spierenburg, F. Danielsen, T. Elmqvist, and C. Folke. 2017. Weaving knowledge systems in IPBES, CBD and beyond-lessons learned for sustainability. Current Opinion in Environmental Sustainability 26-27:17-25. https://doi.org/10.1016/j.cosust.2016.12.005

Tessmann, G. 1930. Die Indianer Nordost-Perus: Grundlegende Forschungen für eine systematische Kulturkunde. Friederichsen, de Gruyter, Hamburg, Germany.

Toledo, V. M. 1992. What is ethnoecology? Origins, scope and implications of a rising discipline. Etnoecológica 1(1):5-21.

Toledo, V. M., and N. Barrera-Bassols. 2009. A etnoecologia: uma ciência pós-normal que estuda as sabedorias tradicionais. Desenvolvimento e Meio Ambiente 20:31-45. https://doi. org/10.5380/dma.v20i0.14519

Turetsky, M. R., B. Benscoter, S. Page, G. Rein, G. R. van der Werf, and A. Watts. 2015. Global vulnerability of peatlands to fire and carbon loss. Nature Geoscience 8(1):11-14. https://doi. org/10.1038/ngeo2325

Virapongse, A., B. A. Endress, M. P. Gilmore, C. Horn, and C. Romulo. 2017. Ecology, livelihoods, and management of the Mauritia flexuosa palm in South America. Global Ecology and Conservation 10:70-92. https://doi.org/10.1016/j.gecco.2016.12.005

Walker, H. 2013a. State of play: the political ontology of sport in Amazonian Peru. American Ethnologist 40(2):382-398. https:// doi.org/10.1111/amet.12028

Walker, H. 2013b. Under a watchful eye: self, power, and intimacy in Amazonia. University of California Press, Berkeley, California, USA. https://doi.org/10.1525/california/9780520273597.001.0001

Wartmann, F. M., and R. S. Purves. 2018. 'This is not the jungle, this is my barbecho': semantics of ethnoecological landscape categories in the Bolivian Amazon. Landscape Research 43 (1):77-94. https://doi.org/10.1080/01426397.2016.1269882

Weber, J. C., and C. Sotelo Montes. 2005. Variation and correlations among stem growth and wood traits of Calycophyllum spruceanum Benth. from the Peruvian Amazon. Silvae Genetica 54(1):31-41. https://doi.org/10.1515/sg-2005-0005

Wilson, E. O. 2016. Half-Earth: our planet's fight for life. Liveright, New York, New York, USA.

Witzig, R., and M. Ascencios. 1999. The road to indigenous extinction: case study of resource exportation, disease importation, and human rights violations against the Urarina in the Peruvian Amazon. Health and Human Rights 4(1):60-81. https://doi.org/10.2307/4065168 